\title{
ENSAYO SOBRE EL SISTEMA DE TRANSPORTE EN ATITLAN, GUATEMALA: UN LAGO MAYA DE TIERRAS ALTAS*
}

\author{
Carlos Navarrete C. \\ Instituto de \\ Investigaciones \\ Antropológicas, UNAM. \\ Elsa Hernández Pons \\ Dirección Monumentos \\ Históricos I.N.A.H.
}

\section{Introducción}

Este trabajo sobre la navegación entre los mayas de Atitlán, es el apartado de una investigación mayor que tratará sobre los sistemas de comunicación prehispánica en esta área de las Tierras Altas.

Escogimos Atitlán, por ser el lago sobre el que existe mayor información etnográfica escrita, que abarca renglones importantes del habitat, formas de vida y actividades económicas de tres etnias mayanses distintas -zutuhiles, quichés y cakchiqueles (Lothrop, 1929a: 216) -, que participan de los beneficios del lago, y por lo tanto del sistema de transporte que nos ocupa.

El lago de Atitlán (Figura 1), se encuentra en el departamento occídental de Sololá, a $1500 \mathrm{~m}$ sobre el nivel del mar, en el centro de una cadena volcánica que corre paralela a la costa guatemalteca del Pacífico; lo rodean tres volcanes - Atitlán, Tolimán y San Pedro- que se elevan hasta $3500 \mathrm{~m}$ de altura (Zamora, 1976: 153). Dos de ellos se localizan directamente sobre el lago: el San Pedro hacia el suroeste y el Tolimán al sur; un brazo del lago se extiende entre estos volcanes, y hacia el oriente del segundo hay muchos lugares relativamente planos en la orilla, donde se sitúan los pueblos;

* Este trabajo fue presentado en el simposium Modo de vida lacustre: continuidad y cambio, en la XVIII Mesa Redonda de la Sociedad Mexicana de Antropología, Taxco, Gro., agosto de 1983. 
del lado norte desembocan tres ríos que forman grandes gargantas, haciendo deltas en su tramo final (Sol Tax en SISG, 1968: 19).

Una exacta descripción del medio en el que se desenvuelven esas comunidades, es la de McBryde (1960, I: 32):

Aquí se encuentra un mayor grado de diversificación microgeográfica que en cualquiera otra parte de Guatemala; posiblemente, no es excedido en otra parte del mundo. Muchos de los poblados pueden estar separados 2 millas o menos entre sí y, aunque aislados por barreras físicas como promontorios escarpados, riscos en las márgenes y la superficie peligrosa del lago, tienen distintas economías, vestuario y aun vocabularios. En un punto a la orilla del lago, los pueblos no están enlazados entre sí ni aun por veredas, mientras que en otros existen veredas tortuosas bordeando precipicios. Grandes variaciones de altura tienen como resultado contrastes climáticos, desde las condiciones tropicales calientes en los niveles más bajos, a las frías cumbres- montañosas, con vegetación que varía desde condiciones de densos bosques tropicales húmedos como detrás de San Buenaventura, a bosques marcadamente caducos de achaparrados encino y pino y chaparral mezclado con áreas abiertas de zacate arracimado y praderas. Dentro de una zona de elevación casi vertical de 600 metros, las cosechas varían, de caña de azúcar a trigo y patatas; en cuanto a frutas, de papayas a melocotones.

Agréguese a esto la convergencia de tres áreas lingüísticas, así como la reciente inyección de varias comunidades pequeñas de regiones remotas en diferentes direcciones.

En perspectiva histórica, este autor (II: 277-280) se inclina, sobre el análisis de fuentes, a que las márgenes del lago estuvieron ocupadas originalmente por zutuhiles, que las dividieron con los recién llegados cakchiqueles. El quiché sería reciente.

Arqueológicamente, hay ocupación desde el formativo o preclásico superior a partir de 500 a.C., con las siguientes fases (Lothrop, 1933; Borhegyi, 1959) :

$\begin{array}{lr}\text { Chukumuk I } 500 \text { a.C }-200 \text { d.G. } \\ \text { Chukumuk II } & 200 \text { d.G. }-600 \text { d.G. } \\ \text { Chuitinamit. } & 1000 \text { d.G. }-1524 \text { d.G. }\end{array}$

Lo que se ha hecho en arqueología hasta ahora es limitado; y si vemos en qué fecha cae el trabajo de Lothrop, también podemos decir que es añejo, y que prácticamente muy poco se ha adelantado desde aquellas exploraciones pioneras. Con Lothrop se obtuvo información de 20 sitios, conectados en una u otra forma con el lago. 
Sus materiales son importantes en cuanto a abrir el conocimiento de una región, pero no pueden darnos más allá de lo que se planteó el arqueólogo en su momento: una cronología, la definición de algunos grupos cerámicos para hacer relaciones externas, descripción detallada del área de montículos de 2 sitios principales, escultura -algunos de sus relieves los hemos usado como ejemplos de influencias del centro de México en el Posclásico (Navarrete, 1976: $360)$ - lítica, y algo de etnografía. Nuestra Figura 2 es una adaptación del dibujo de Lothrop de la orilla sur del lago y sus antiguos asentamientos.

Actualmente, no sólo estamos necesitados de que se practique un nuevo reconocimiento, sino de que se trate el aspecto "vivo", social y económico, que la arqueología busca ahora. Algo de eso intentamos aquí, con esta aproximación documental del medio laçustre; es la razón por la que dedicamos una parte considerable del trabajo a rastrear, histórica y etnográficamente, los alimentos y materias primas que se dan en esa gran olla volcánica, donde el lago es paso obligado.

Agricultura, pesca, artesanías

Quizá la mejor vivencia, expresada por un cronista de la colonia, sea la de Fr. Francisco Vásquez, quien no se quedó corto al escribir sobre las ventajas que las tierras atitecas ofrecían a toda clase de siembras y de las cualidades de los frutos, así como del intercambio con la tierra caliente (1937, I: 171):

Danse muchos frijoles, que llevan a vender a otras partes, en especial a la costa y provincia de Suchitepéquez, que para ellos es un día de camino; dase el chan con abundancia, de que se saca de aceite, como de linaza, y de más a más, sirve para las bebidas frescas contra el calor y para el sustento de pájaros de jaula. El anís que se coge es mucho, en especial a la banda del Norte, cominos, garbanzos, habas, ajos, cebollas, lechugas, repollos y todo género de hortalizas, se da admirablemente con mediano cuidado que haya.

De las frutas de Castilla, hay granadas, membrillos muy buenos, duraznos aunque pocos, e higos con abundancia, naranjas, limo nes, toronjas, cidras, limas agrias, limas dulces; por lo apetecible del temple, da de sierra y de costa; esto es, de tierra fría y caliente; ya que queda dicho lo de tierra fría en lo de las frutas de España y hortalizas; de la caliente da plátanos de regalo, za- 
potes, injertos muchos, anonas, matasanos, tunas, jocotes, tantos que los pasan al sol y los llevan a vender a la costa por cacao (que es la moneda de vellón, con que se remedian los de otras tierras apartadas), sacándole por ocote, amole (que es su jabón), escobas, ollas, jarros, sillas, bancos y cuantas baratijas no tienen salida en sus pueb'os, porque la abundancia y riqueza del cacao, hace pródigos a los dueños (y compran aún lo que no han menester), cañas dulces, algodón (aunque poco), flores muy olorosas blancas y rosadas de la costa, aguacates muy sabrosos, en especial hay unos árboles en el pueblo de San Pablo que los dan tan grandes que seis de ellos se envían por regalo a esta ciudad, porque son como melones y de lindo susterito; en conclusión, los moradores de estas riberas no padecen las hambres que en otras partes, porque además del socorro que tienen, sin contingencias en las aguas de la laguna, el temperamento de la tierra por ser medio, ni padece heladas como los altos, ni los fuegos, de lo bajo de la costa, y de más a más casi todos los pueblos tienen agua de pie y que se desgalga de los altos, para el regadío de plantas, ayudándose del chile (salsa común de los indios), batatas, yucas, pacayas y otras yerbas, con que se hacen varios platillos de viernes: casi todo el año es cuaresmal para los pueblos de San Pedro, San Juan, San Pablo, San Marcos, Santa Cruz, Santa Catarina, y San Antonio Palopó que rara ve' comen carne, y ésta hallándole acaso de venado, puerco, puerco montés, o cosa tal, porque viven contentos, quietos y satisfechos, con lo que Dios les da cerca de sus casas, pasando la vida alegres sin el ruido, ahogos y dineros, que cuestan a otros la opulencia y regalo, madrastra de las virtudes y polilla de la vida, que se contenta con poco y se pierde con mucho.

Los antecedentes bibliográficos sobre estas cosas se remontan hasta el siglo xvi con la relación de Santiago Atitlán, donde hay descripción menuda de las propiedades de las plantas que en ese tiempo asombraban y se buscan respuestas a necesidades de canteras y salinas (Acuña, 1982: 65-150).

Quien rastree la historia de los cultivos y el aprovechamiento del lago, notará a partir del xvir, que se ha ido adquiriendo un mejor conocimiento de la región. El citado Vásquez es un ejemplo, también Fr. Diego de Ocaña (1932: 297), o el padre Bernabé Cobo (Cuevas, 1944: 195), que en una sola frase sintetiza la diferencia de climas tan cercana: "...en uno de ellos (los pueblos) hay higos verdes todo el año y en otro que sólo dista media legua, hay duraznos todo el año..."

Hay breves alusiones en Manrique de Guzmán en 1740 (1935: 19), o detallados y muy xvin como la disertación de Fuentes y Guzmán (1933, II:66) de la que reproducimos su mapa del Corregi- 
miento de Atitlán (Figura 3). En cambio, hay parquedad en el obispo Cortés y Larraz (1958: 160).

Hoy en día, todos los pueblos del lago participan de cultivos comunes, necesarios para su propia dieta, aparte de algunas siembras especializadas que les permiten las características de las tierras que poseen y de las que han hecho un rénlgón comercial. La mayo. ría de los cultivos son verdura y frutos, además de las semillas tradicionales, maíz (Butler y Dean, 1977), y frijol, y las europeas como trigo y café. En cuanto a la accesibilidad a una gran variedad de productos, citamos nuevamente a McBryde cuando describe el corredor natural de Santiago Atitlán, que enlaza el atiplano con la costa (Ob. cit., II : 295) :

Hacia el norte están los elevados campos de trigo, arveja, frijos, manzanas, melocotones y papas en abundancia, huertas de cebollas y verduras de tierra fría; telares de lana y algodón; caleras; productos de alfarería y carpintería. Hacia el sur, las plantaciones de la costa de caña de azúcar y café (aunque de alta calidad, el café del lago está limitado en su cantidad); frutas tropicales de toda clase, especialmente piñas, zapotes y nances; algodón, cacao, sal, chile y achiote, flores y hojas de palma, pescado, camarón, lagartos e iguanas. Las orillas del lago proveen de aguacates, frijol, naranjas, limas, tomates, matasanos, caña de azúcar, ajo, jocotes (Spondias sp.), cangrejos, pescado pequeño, lazos, anís y garbanzo superior.

Cualquier estudio sobre la economía lacustre prehispánica, tendrá que partir de la actual distribución de los cultivos, para seguir retrospectivamente las innovaciones en las siembras y en las técnicas de preparar el terreno. Muchos de los nuevos sistemas de terrazas, en la zona de Panajechel, destruyeron antiguos terraceados prehispánicos del tipo de los que Lothrop observó en Chuitinamit (Ob. cit., Fig. 47); y cabe la posibilidad de que el cultivo por "camellones" y canalizaciones abiertas desde la orilla del lago -que dan una impresión de "falsa Chinampa"-, fuera antiguo (Figura $4)$.

Para nuestro fin, los datos contemporáneos son demasiado globales, y obtenidos y analizados con otra intención. Etnohistóricamente nos interesa lo que estos estudios suelen dejar a un lado: el producto menudo, "orillero", el que se da silvestre y completa la alimentación familiar; la raíz de una planta acuática, la hoja medicinal para infusorios, las yerbas que crecen en las distintas estaciones y partes del lago. Hay berros y tubérculos no registrados 
por los científicos sociales, y a los mercados llegan frecuentemente los canastos de jutes (molusco de agua dulce, Pachychilus); parvadas de pájaros acuden a las orillas, y el conejo y la ardilla $-\mathrm{y}$ antes el venado- las frecuentan. McBryde ha hecho el mejor enlistado de plantas cultivadas aborígenes (Ob. cit., II: 379-429). Otra fuente de primera mano es el clásico libro de Tax (1964).

Sería el momento de hacer destacar la poco tratada fruticultura prehispánica, a partir de la presencia actual en todos los pueblos del árbol de jocote, la "ciruela de la tierra" como la llamaron los conquistadores. Serrano (1970: 22) pone a Atitlán como el centro jocotero del país. Otro fruto, el aguacate, fue saboreado en 1586 por Ciudad Real (1976, II: 20); y la especie autóctona, pequeña y de cáscara dura, continúa llenando las redes de los comerciantes.

Igualmente se tendrán que ver otras actividades económicas como la pesca y las artesanías, que llegan a constituir la principal fuente de ingresos en más de un pueblo. En San Pablo, la industria se basa en el cultivo del henequén, de donde se extrae la fibra para laborar hilo y cuerda para realizar redes, hamacas y bolsas. Lothrop (1929 b: 120) habla de la participación familiar en su elaboración. San Pablo produce gran parte de los lazos usados en las fincas de la costa, para volver a tocar el tema del intercambio con la tierra caliente. A fines del xvmr, Panajachel obtenía buen pago de hacer mecates y cuerdas, "por tener mucha pita y bien cultivada" (Cortés y Larraz, Ob. cit., 167).

Sobre las artesanías y su distribución, habrá que tomar en cuenta en qué forma participan las poblaciones del lago y cuáles son recientes, ya que algunas parecen estar determinadas por la escasez de tierras de cultivo.

Las fuentes no son muy explícitas en lo que a pesca se refiere, y en ocasiones dan la impresión de que no fuera sobresaliente, quizá debido a que el pececillo nativo es, por lo general, motivo de curiosidad y a veces menosprecio. Parece que desde el siglo xvi se comienzan a introducir especies europeas como la mojarra (Ciudad Real, Ob. cit., II: 19). Vásquez nuevamente nos transmite su vivencia de la actividad que engendraban estos pececillos (p. 167):

Es tan frígida, que el más nadador no puede detenerse en sus aguas como en las de mar y ríos, porque en breve tiempo (como se ha conocido por experiencia) se halla cortado e impedido de un calambre que le obliga a procurar su remedio saliendo, si está cerca de la orilla, o pidiendo socorro de alguna canoa, que hay copia de ellas donde se permiten; la pesca que da es de cangrejos y pescaditos, en abundancia, que se llaman de Atitlán; 
son como el dedo meñique, y otros, aún menores que la mitad, son el sustento de sus comarcanos y aun mayor ganancia; porque asados al fuego los mayores ensartados en unas pajas gruesas como de centeno, y fuertes como varillas, trajinan y comercian con ellos por muchos lugares y provincias; y de aquí sacan cacan y dinero con que pagar el tributo, y socorrer sus comunes necesidades. No da peje grande ni nocivo fuera de lo dicho; verdad es, que alguna vez, aunque rara, se ha cogido tal o cual mojarra de más de.cuarta y cuatro dedos de largo, y muy ancha y gruesa, tierna y de lindo gusto; pero son pocos los que las han visto o comido, y muchos los que por fe saben que las hay; éstas se han hallado muy acaso con interpolación de años; dícese que no pican en el cebo del anzuelo, ni hacen caso de él, y se discurre que es por la abundancia del peje menudo que tienen en cualquier parte de la laguna, con que se sustentan fácilmente; porque ya se sabe, y es uso antiguo y recibido, que los pejes grandes se comen a los pequeños, conque si faltaran los pequeños, los grandes perecieran.

Según William G. Douglas (SISG, 1968: 250), hay cuatro especies de estos pequeños peces a los que simplemente se les conoce como "pescaditos". El más pequeño alcanza una longitud de $9 \mathrm{~cm}$ y habitan en la zona de aguas poco profundas. Tanto este autor como Serrano (Ob. cit., 15), dicen que, además del pescadito es importante el cangrejo de agua dulce, al que ya se refería el capitán Fuentes y Guzmán en el xvir, quien no gustó mucho de los pececillos indí. genas (Ob. cit., 65).

Si bien, no todos los pueblos se dedican a la pesca, ésta ha disminuido considerablemente desde 1950 con la introducción de la "lobina de boca grande", que devastó la fauna lacustre. Este voraz pez, se introdujo junto con otras especies que les servirían de comida, sin embargo, prefirió a los "pescaditos" hasta que los agotó. La lobina no se atrapa con garlo, sino con anzuelo y sedal. También acabó con los cangrejos; ya no es fácil encontrarlos en aguas poco profundas y son mucho más pequeños, lo cual ha repercutido en los mercados de Sololá y Tecpán a donde se llegan a vender.

Por el uso de canoas, es importante saber que Santa Catarina fue un pueblo - por lo menos todavía en los cuarentas - que vivía principalmente de los productos del lago (Flavio Rojas Lima, en SISG: 316$)$ :

El cambio más importante que se registra en la historia reciente de esta población, es el relativo a las fuentes de subsistencja de sus moradores. En la época que sirve de punto de comparación a las presentes observaciones y aun varios añcs después, Santa 
Catarina era un pueblo que vivía principalmente de los productos del lago. Ciasi podía colocarse en un mismo plano la agricultura en pequeña escala propia de la región, con la recolección de especies lacustres, en lo concerniente a la economía particular de muchas familias y a la del poblado en su conjunto. Muchas eran, en efecto, las personas que se dedicaban a la pesca, y una apreciable cantidad de cangrejos y peces se destinaba a los hoteles de Panajachel y a los mercados de este último pueblo de Sololá y de otros más. Se decía de Santa Catarina, con prioridad, que era el pueblo pesquero por excelencia de todos cuantos están situados en la orilla del lago. Esta situación ha variado de manera notoria. "Ahora ya no se puede comer del lago", expresaba un informante, agregando que inclusive el tul, que crecía es. pontáneo y abundante en las aguas ribereñas y que los catarinescos aprovechaban para la fabricación de petates en número considerable, ha disminuido notablementè en comparación con otras épocas.

Una de las causas que han afectado más las disponibilidades de tul en las playas de Santa Catarina, de acuerdo con los informes de McBryde y de Tax, es la constante subida del nivel de las aguas del lago, cuyos comienzos fija el primero de los autores citados en el año de 1933.

Al igual que Rojas Lima, transcribimos a Sol Tax y su experiencia de 1935, con las técnicas empleadas en la pesca en este mismo pueblo:

La pesca de peces y cangrejos y la hechura de petates alcanzan las proporciones de industrias en Santa Catarina; la mayoría aunque no todos los hombres del pueblo saben cómo pescar, capturar cangrejos y hacer petates; mas entre ellos saben cómo practicar dos de estas tres actividades, y todavía más, al menos unja. Hay algunas variantes de la pesca; un anzuelo y su cordel, con cebo; una canasta cónica al extremo de una vara, con el cebo atado a la boca de la canasta; pesca en agua caliente con una canasta cónica muy grande, y pesca desde la playa. Muy pocos hombres practican la pesca en agua caliente, y menos todavía la pesca desde la playa, puesto que para hacerlo se necesita ser dueño de ésta. Todos los utensilios son hechos en Santa Catarina por los mismos pescadores. La pesca del cangrejo requiere un bejuco de diez o quince yardas de largo, con cebos atados a intervalos, enrollado todo y dejando fuera del agua. Los pescadores de cangrejos van ellos mismos a las colinas a conseguir los bejucos quie crecen sobre ciertos árboles.

El saber pescar o coger cangrejos implica saber cómo usar una canoa, dónde pescar, y por lo general saber construir los utensilios necesarios. Hay gente en la mayoría de los pueblos del lago que sabe estas cosas; pero el porcentaje es mucho mayor en Santa 
Catarina. En los últimos años se ha cobrado un quetzal por mes en calidad de impuestos por licencia para pescar, y afectivamente ha recaido sobre la mayoría de los "conocedores" fuera del lago; pero no en Santa Catarina, porque tal licencia no se exige a los catarinecos - una excepción - permitida a propósito, porque la pesca es muy necesaria para el mantenimiento de la gente.

También McBryde (Ob. cit., II: 347), explica las causas del abandono de esta actividad. En las páginas 490-91, describe las técnicas de pesca y la forma de llevar el producto al mercado. Tam bién toca el decaimiento del corte de tul para la industria de petates. Ofrecemos una ilustración del corte de esta planta silvestre (Figura 5).

Concluimos con un animal totalmente identificado con estas aguas de corrientes frías: el pato zambullidor, Podilymbus gigas (Davis, 1972, fig. 12), llamado en lengua quiché Pok, con derivación a Mok (Serrano, Ob. cit., 175).

Esta especie sólo vive en Atitlán; es un ave pequeña parecida a los patos (Figura 6,a) su conformación anatómica no le permite extender su vuelo y resiste mucho tiempo debajo del agua (Ibarra, 1959: 33-37).

Siempre ha formado parte de la alimentación indígena. Así lo podría indicar una escultura arqueológica a tamaño natural de una de estas aves (Figura 7), y el dibujo en una vasija del Clásico terminal encontrado en Panajachel (Figura 6,b). Las fuentes coloniales no la mencionan y en los cincuentas estuvo casi a punto de ser extinguida. Rojas Lima (Ob. cit., 318) habla de una especie piscícola -el "black bass" - introducida experimentalmente por una dependencia gubernamental, la cual por su gran voracidad, no sólo exterminó casi por completo los peces menores, sino causó estragos en los huevos y polluelos del zambullidor.

Como dato aparte en 1959 un decreto presidencial declaró al pato monumento nacional para protegerlo. Interesante es que, como siempre, la culpa humana de su extinción se la echara el naturalista oficial (Ibarra, Ob. cit., 35): "... a la ignorancia de nuestros indígenas que cazan el zambullidor para su subsistencia cotidiana", olvidando que, por siglos, los indígenas y el Pok siempre pudieron convivir.

Para apreciar el juego comercial de estos productos en el rol de los mercados de la región, véase el cuadro elaborado por el Instituto Indigenista Nacional (IIN, 1966: 60), del circuito de Mercados Regionales de la República de Guatemala, en nuestro caso, lo que se 
refiere a la cabecera departamental en Sololá. Como organización interna de mercado, está la lista de vendedores y de artículos del mismo Sololá, dado por McBryde (Ob. cit., II: 312-337).

\section{Canoas y conexiones terrestres}

Impresión característica del paisaje atiteco son sus canoas, de forma diferente a las que conocemos en Mesoamérica. Es una piragua con adaptaciones quizá posteriores, cuya base - por lo menos las viejas - son enormes troncos ahuecados de cedro, con capacidad hasta para 30 ó 40 personas. Así eran cuando las describió Lothrop (1929a: $21 \overline{6} ; 1933)$. En ese tiempo, la canoa más grande tenía $11 \mathrm{~m}$ de largo, con una borda de $1.60 \mathrm{~m}$. Pertenecía al municipio y aún se le recuerda: la Capoj Tzutuhil.

Una canoa mediana actual, de uso familiar, tiene $3.70 \mathrm{~m}$ de largo y sus lados $0.66 \mathrm{~m}$ de altura. Son más fáciles de manejar y perfectas para la pesca individual (Figura $8, a, b$ ).

El casco está hecho de una sola pieza de árbol (Figuras 9 y 10), del que sobresale una pequeña borda de pino de 0.15 a $0.32 \mathrm{~m}$ de alto; sin embargo, no todas las canoas tienen ese agregado y su aparición probablemente sea por influencia europea. Es de hacer notar que carecen de asiento. Lothrop hace ver que es poco común que se raje el casco, a pesar de las aguas tan agitadas y las rocas de las playas. Cuando se estropea se saca del agua, se repara con resina de árbol y por el interior se clavan tablillas en la zona de la grieta (Lothrop, 1952: 203-210).

Las canoas tienen una cabilla al frente y dos en la popa, que sirven para transportarla fuera del agua. El remo es de paleta y carecen de timón. Las embarcaciones son manejadas únicamente por hombres. Según McBryde (Ob. cit., II : 296), la mayoría de las canoas del lago se fabrican en Santiago, y unas pocas en San Pedro, el único otro lugar en el lago. Experiencia probada la del primiero, que en 1936 tenía una flota de 250, diez veces más que los pescadores de Santa Catarina, cuando los otros pueblos apenas llegaban a 4 ó 5 canoas cada uno.

Probablemente tenga razón Lothrop, en eso de que las bordas superpuestas al casco sean de origen hispánico, como protección contra el oleaje. De ser indígena sería caso único entre los antiguos mayas, porque todos los ejemplos comparativos que hemos reunido son de canoas de fondo plano y de una sola pieza. El antecedente 
más dírecto está representado en la estela 67 de Izapa (Figura 11,a), con un perfil semejante al de la pequeña canoa olmeca de jade que diera a conocer Covarrubias (Figura 11,b). El diseño izapeño pudo haber sido tomado en las cercanas lagunas de esteros, en donde se hacen de ceibas o pochotas; las de mayor tamaño llevan una prolongación en la popa parecida a las que muestran en los extremos los ejemplos anteriores (Figura 12).

Su uso antiguo, cotidiano, en la cadena de lagos del Petén - expuesto por el cronista de la reducción de los itzaes en 1696, Villagutierre Soto-Mayor (1933: 346), al narrar los hechos de la toma por agua de Tayasal-, podría haber inspirado la forma que asumen las canoas en los huesos esgrafiados de Tikal con esa doble saliente (Figura 13,b).

La semejanza fue notada por Acuña (Ob. cit., 66), entre las embarcaciones de la pintura de la Relación de Santiago Atitlán y las barquillas que aparecen flotando en un fresco de Chichén Itzá, con el boga y los pasajeros puestos de pie (Figuras 14 y 15). Otros ejemplos tardíos de esta forma dominante en la iconografía prehispánica, los tenemos en el Códice de Dresde (Figura 13,a). Un buen modelo, casi "a escala", es la canoita - $15 \mathrm{~cm}$ - tallada en un hueso de manatí proveniente de Moho Cay, Belice (Healy, 1980:4).

Antes de afirmar que así eran todas las embarcaciones mayas, hay que tomar en cuenta que nuestra información procede de materiales arqueológicos de élite, en los que estaría presente una forma tradicional de mostrar canoas importantes; por algo transportan personajes de rango, deidades y guerreros.

Éstas podrían ser propiamente canoas, basándonos en la imprecisa definición de que es una embarcación de regular tamaño, de una sola pieza, sin quilla, con la proa y la popa iguales; para diferenciarla de los cayucos, a los que el inefable diccionario oficial de nuestra lengua describe como "embarcación india de una pieza, más pequeña que la canoa, con el fondo plano... que se gobierna y mueve con el canalete". Para Francisco J. Santamaría (1921: 340), es difícil diferenciar los dos tipos de embarcaciones, sin embargo: "El cayuco es la embarcación menor, propia de las aguas continentales, ríos, arroyos, lagunas, construida de una sola pieza, del tronco de los árboles escarbados. Desde que el cayuco es de tales dimensiones que puede dar cabida a varias personas y se puede viajar en él con ciertas comodidades, se llama canoa...".

El cayuco, como término de uso popular, es también el transporte de menor tamaño, con los extremos terminados en punta lige- 
ramente curva, sin aditamentos interiores, con el fondo del tronco ahuecado semiplano, y que constituye una parte fundamental del patrimonio familiar cuando en su economía participa la navegación.

Son los que vemos en otros lagos del Área Maya. Hay una vieja fotografía de Amatitlán (Figura 16), lugar donde prácticamente han sido desplazadas por canoas de doble remo y manejo sentado; el tráfico de cayucos continúa siendo importante en la cadena de lagos de Petén Itzá (Reina, 1966: 16), y en las lagunas y ríos de la Selva Lacandona de la costa de Chiapas (Figura 18,a), e igual puede decirse de las que remontan las rutas fluviales que bajan al Golfo (Figuras $18, b ; 19$ ). Hay trabajos escritos sobre estos sistemas costeros de comunicación (Navarrete, 1973: 41; Lee, 1978: 49; Hernández Pons, 1984: 45; Navarrete y Lee, en preparación), y sobre la navegación maya por mar, que aquí no tocamos (Quezada y Luna Rivas, 1981: 43).

La diferencia podría estar en los medios donde operan y en la pericia que el conductor adquiere para sortear las distintas dificultades que impone un río, el terreno fangoso de un canal entre manglares, o un lago de aguas profundas. Por eso, en Atitlán, uno de los conocimientos básicos de todo buen navegante, es el de los vientos, a los que adaptan los horarios de transporte y pesca. Por ejemplo, la travesía del lago se hace de madrugada para evitar el fuerte oleaje que levanta el viento del sur. Hay meses en que sopla el temido chocomil o "remolino", cuya fuerza y corriente impiden toda actividad a medio lago (McBryde, II: 295; Serrano, Ob. cit., 81).

A manera de contraste, mostramos las balsas que se usan en Yolnajab o Laguna Brava, en el norte de Huehuetenango. Son hechas de un árbol de madera suave, que flota. El embarcadero principal está en Yalambojoch, cuyos aldeanos, de lengua chuj, son los propietarios de la mayoría de las balsas que transitan la laguna (Figura 20). Tienen capacidad para cargar 6 quintales - generalmente sacos de café-, y los campesinos las emplean básicamente para llegar a sus siembras del otro lado, donde comienza el descenso a tierra caliente.

Volviendo a Atitlán y sus canoas, hay aquí una necesidad vital de emplearlas. El lago es barrera no solamente para los pobladores de sus márgenes, sino, como veremos adelante, para un brazo del sistema de caminos terrestres entre la costa y el altiplano occidental. Dentro del contexto de la red de caminos, unos pueblos del lago requieren más que otros de su uso constante. De eso ha dicho Tax (SISG, Ob. cit., 25) : 
Puede afirmarse, como regla general, que los pueblos que hacen más uso de canoas para transporte son los que más la necesitan, a los cuales, en efecto, son aquéllas casi esenciales: en primer lugar, Atitlán, donde la gente está separada por el agua de la mitad de sus tierras maiceras y que, además, está aislada grandemente de los pueblos del norte; en segundo lugar, un pueblo como Santa Cruz, que casi se ve obligado a comerciar y desde el cual la distancia hacia Sololá se acorta en menos de la mitad por un viaje en canoa, y es significativo que aún así la gente viaje por tierra tanto como debiera hacerlo por vía acuática; en tercer lugar, Santa Catarina, y éste parece ser una excepción: prácticamente todo el viaje es hecho por tierra, y sin duda las distancias no son tan grandes; pero las canoas se usan generalmente en la pesquería.

Ahora bien, el entronque mayor y razón del movimiento comercial que transita el lago, es el que conecta los principales embarcaderos - Atitlán, Panajachel y un poco menos San Lucas Tolimáncon los caminos terrestres de la costa y las tierras altas de Guatemala, con sus posibilidades de conexión (Figura 21).

Vale la pena detenerse en lo que significa el embarcadero de Santiago Atitlán. De gran importancia comercial, el pueblo está situado en una abra entre los volcanes Tolimán-. Ititlán y San Pedro, en un corredor natural que enlaza el altiplano con la costa en una antigua ruta principal. Como anota McBryde, es una localidad donde se bifurcan los caminos, al converger las rutas del lago con las terrestres, dando accesibilidad a esa variedad de productos a que nos hemos referido, lo que ayudaría a explicar la predisposición de los santiagueros a ser buenos navegantes (II: 296):

Dentro de tal marco, es comprensible por qué los atitecos pudieron convertirse en intermediarios y navegantes profesionales que transitan por el lago en pequeña escala. Hacia el lado oeste tienen buena madera de construcciôn en las montañas, una bahía abrigada y en parte poco profunda, con numerosas entradas menores y maizales más allá, que muchos hombres visitan sólo en canoa. Bajo estas condiciones, la destreza en el manejo de las embarcaciones se adquiere rápidamente desde la niñez. ( ...) Veinte o treinta y durante el máximo periodo de la cosecha aun 80 cayucos rompen diariamente la tranquilidad de la madrugada en la bahía de Santiago, con uno y a veces dos o cuatro atitecos de camisas blancas en cada cayuco, remando afanosamente a través de Santiago rumbo suroeste a la ribera opuesta a una milla o más de distancia. Llegan en unos 20 minutos y caminan hacia sus milpas en las faldas del volcán de San Pedro.

Para cruzar la bahía emplean pequeñas canoas, cuya longitud promedio es de $41 / 2$ varas $(9 \mathrm{~m})$. Emplean otras mucho más grandes para atravesar el lago, un viaje de 9 millas de Santiaga 
a Panajachel que se realiza en unas 4 horas. (...) La travesía del lago se hace de madrugada (usualmente de 4 a 8 horas), para evitar el fuerte oleaje que viene con el viento sur, y que principia alrededor de las $8.30 \mathrm{am}$. (...) Los transportistas del co rreo (llamados pescadores) de Santiago, son remeros municipales, usualmente de cuatro a seis, que proporcionan una travesía diaria para pasajeros, que desembarcan en la playa en Panajachel y caminan hacia Sololá. Hombres, mujeres y niños con cargamentos de toda clase, incluyendo cerdos, son llevados en esta forma a través del lago. La mayor canoa, "La Capoj Tzutuhil", es de propiedad municipal y es el orgullo de la flota; tiene $11 \mathrm{mts}$ de largo por $35 \mathrm{cms}$ de ancho y por lo general lleva 16 pasajeros además de 4 pescadores, que recibían 8 centavos (pedían 10) por la travesía. Los atitecos son lancheros expertos, usualmente los mejores del lago y ellos invariablemente ganan la regata anual đel lago de Atitlán. Los pescadores de Santa Catarina son posiblemente $\tan$ expertos como los atitecos en maniobrar canoas pequeñas, como esas en que han pasado mucho de su tiempo pescando y buscando cangrejos.

Cuando este autor hizo la investigación, pasaban embarcados de 200 a 300 comerciantes a los mercados costeños de fin de semana. De un movimiento semejante y actividades mercantiles durante la Colonia, hay unas frases de Fray Francisco Vásquez (Ob. cit., 170).

De las relaciones comerciales externas de este pueblo, seguramente algo indica que en el siglo xvr los indios viejos, principales, entendieran el mexicano - la lingua franca prehispánica-, como lo dice la Relación de Santiago Atitlán (Acuña, Ob. cit., 86).

Un brazo del camino real colonial lo tocaba básicamente durante la época de seca. Fray Alonso Ponce paró aquí a fines del siglo XVI en su viaje de México a Guatemala, habiendo recalcado la imposibilidad de paso durante algunos meses de lluvia, en los que había una disminución de pasaje en canoas de los que atravesaban el lago para tomar esta ruta (Ciudad Real, Ob. cit., 19).

Entonces, el camino que atravesaba las tierras altas de Guatemala y Chiapas, tocaba Panajachel en la orilla del lago, bajando de Godines, y subía hacia Sololá para encaminarse a Totonicapán y Huehuetenango. entrando al territorio chiapaneco (Navarrete, Ob. cit., 72-80).

Hay otra salida a la costa, paralela a la de Santiago. Bajaba también de Godines - punto obligado del camino real a Chiapasa Tolimán, situado también en otra especie de abra, con embarcadero importante, de donde parte el camino que hoy baja a Patulul en la costa y al Soconusco. En 1630, el padre Bernabé Cobo lo recorrió, describiendo la vereda de tres leguas entre Tolimán y San- 
tiago, que bordeaba el lago y lo enlazaba con estas dos puertas, a la cosa (Cuevas, Ob. cit., 195).

El que los pobladores de Tolimán no llegaran a alcanzar la misma jerarquía de Santiago como "mercaderes del lago", lo atribuye McBryde a su menor extensión de tierra arable y a que, pese a estar en una ruta de paso más fácil, su bahía no posee el abrigo ni las condiciones de navegabilidad que la de Santiago.

La apertura de veredas entre poblados, siguiendo las márgenes del lago, no siempre es posible, como ocurre entre Tolimán-Santiago-San Pedro-San Juan, debido a lo abrupto y cortado de algunas partes, lo que hace necesario subir de cota hasta tocar con otros caminos, para luego bajar otra vez a los pueblos orilleros.

De ahí la comodidad de transportarse en canoa entre algunos puntos, como se hace ver desde el siglo xvi (Acuña, Ob. cit., 84). Nuevamente el cronista de la Colonia que mejor siguió los movimientos de su orden religiosa en estos polvorientos caminos, que de hècho son los senderos actuales, vuelve a ser Vásquez, al pormenorizar sobre las fundaciones conventuales, y qué pueblos administraban (Ob. cit., 171).

Caminando para el poniente (de Santiago) está San Pedro, que se llama de la Laguna, donde hay convento con tres religiosos, para acudir a la administración de los Sacramentos, y enseñanza de los naturales; son por todos los pueblos de esta Guardianía cinco, que son San Pedro, San Juan, San Pablo, Santa Clara y La Visitación, y ninguno sin misa el día de fiesta aunque no sea domingo o de los que obligan a los indios. Todos estos cinco se administran del convento de Atitlán, porque eran de su visita y jurisdicción, y con muy maduro y cristiano acuerdo se separaron, dándoles administración independiente, porque el riesgo y trabajo de acudir por agua (que por tierra es caso imposible) y más en tiempo de Nortes, que soplan en aquella banda con furia, es muy grande. Síguese luego San Juan, no media legua, luego San Pablo, poco más de otra media, adminístrase unas veces por tierra, otras por agua, que es recreación, si la laguna no se enoja. Los otros dos pueblos de Santa Clara y Visitación, están arriba en la cumbre que ya son de tierra fría.

De San Pablo, dando la vuelta, a la laguna, se empieza ya a caminar buscando el Oriente, el primer pueblo que se encuentra en sus orillas es San Marcos, y poco después Santa Cruz, ambos son pequeños y pocas tierras, porque la laguna, por lo bajo, y la sierra empinada, toda riscos, que está cerca del agua se las quita. Estos pertenecen a Tecpanatitlán, pueblo grande que hay allá en la cumbre de donde bajan los religiosos a administrarlos, y para esto forzosamente han de embarcarse en un buen arenal algo resguardado, donde ahora veinte años había un pueblo llamado 
San Jorge, que se destruyó con la venida de un río y el pueblo se fundó en medio de la cuesta por temor de otro tal suceso, era de los más amenos y regalados de aquel contorno, de aquí se va a San Francisco Panajachel, donde hay convento muy alegre, con tres religiosos para la administración, son cinco los pueblos que administra; antes pertenecían al convento de Tecpanatitlán, que está arriba, y es de los grandes y primeros de la Provincia, capitular, como Santiago Atitlán; separándose en el Capítulo Provincial del año de 1641, por la mejor administración. Los pueblos fuera del convento son, la Concepción y San Andrés arriba en los Altos y en la orilla de la laguna Santa Catarina y San Antonio Palopó, que es el primero al oriente. De ahí se va por agua a San Lucas Tolimán, a la parte del Sur, visita de Santiago Atitlán, con que se cierra el número de diez pueblos, están a la orilla de la laguna.

Para terminar con esta sección de los caminos, señalamos la distancia entre los pueblos por vía lacustre, a partir del embarcadero actual de mayor importancia comercial (Serrano, Ibid.: 56) :

\begin{tabular}{|c|c|c|}
\hline Poblaciones & $\begin{array}{l}\text { Linea recta } \\
\text { aprox. } \mathrm{Km}\end{array}$ & $\begin{array}{c}\text { Navegable } \\
\mathrm{Km}\end{array}$ \\
\hline \multicolumn{3}{|l|}{ De Panajachel a: } \\
\hline Santa Catarina Palopó ........ & 3.2 & 3.9 \\
\hline San Antonio Palopó .......... & 6.8 & 7.0 \\
\hline San Lucas Tolimán ......... & 11.1 & 11.5 \\
\hline Santa Cruz La Laguna ...... & 5.0 & 5.2 \\
\hline Santiago Atitlán ........... & 13.1 & 13.5 \\
\hline San Marcos La Laguna ...... & 10.7 & 11.0 \\
\hline San Pablo La Laguna ......... & 11.9 & 11.9 \\
\hline San Juan La Laguna ........ & 13.9 & 13.9 \\
\hline San Pedro La Laguna ........ & 12.6 & 12.6 \\
\hline \multicolumn{3}{|l|}{ De Panajachel a: } \\
\hline Santa Catarina Palopó ...... & 3.2 & 3.9 \\
\hline \multicolumn{3}{|l|}{ De Santa Catarina Palopó a } \\
\hline San Antonio Palopó ......... & 3.8 & 4.3 \\
\hline \multicolumn{3}{|l|}{ De San Antonio Palopó a } \\
\hline San Lucas Tolimán ......... & 6.4 & 6.4 \\
\hline \multicolumn{3}{|l|}{ De San Lucas Tolimán a } \\
\hline Santiago Atitlán ........... & 9.4 & 15.2 \\
\hline \multicolumn{3}{|l|}{ De Santiago Atitlán a } \\
\hline San Pedro La Laguna ........ & 7.0 & 7.8 \\
\hline \multicolumn{3}{|l|}{ De San Pedro La Laguna a } \\
\hline \multicolumn{3}{|l|}{ De San Juan La Laguna a } \\
\hline \multirow{2}{*}{\multicolumn{3}{|c|}{ De San Pablo La Laguna }} \\
\hline & & \\
\hline San Marcos La Laguna ...... & 1.4 & 1.5 \\
\hline \multicolumn{3}{|l|}{ De San Marcos La Laguna a } \\
\hline Santa Cruz La Laguna ....... & 6.0 & 6.3 \\
\hline De Santa Cruz La Laguna a & & \\
\hline 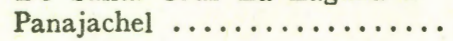 & 5.0 & 5.2 \\
\hline
\end{tabular}




\section{Otros aspectos $y$ dudas}

Todo lo anterior suscita muchas preguntas; inicialmente el problema de la sustitución e introducción de cultivos después de la Conquista y su desarrollo de acuerdo a los cambios demográficos en el tiempo; habrá que considerar que hubo movimientos de población prehispánica - las tres lenguas con ocupación sucesiva de las márgenes-, y que la concentración en poblados durante la Colonia, y el régimen de tributos impuestos a los indígenas (Carrasco, 1982: 234), tuviesurye incidir de alguna manera en las siembras, el intercambio de todo tipo y por ende en el transporte.

De estos aspectos, la arqueología no nos aclara nada. Los sitios descritos por Lothrop en su clásica monografía, se investigaron prácticamente en su ámbito ceremonial. No hay concordancia entre todos los lugares prehispánicos y los asentamientos a partir de la Colonia y hace falta rastrear orillas y playas.

Estamos, por lo tanto, frente a una sucesión de lapsos históricos oscuros, en contraste con la dinámica de los cambios sociales, que en nuestros días se aceleran con los incentivos capitalistas que han convertido a Atitlán en un filón más de explotación turística, precipitando transformaciones radicales como en el caso de Panajachel (Hinshaw, 1957). Las orillas del lago son ahora terrenos codiciados para casas de descanso, como pudimos constatar en San Pedro La Laguna, o como lo ha descrito Rojas Lima en Santa Catarina Palopó.

Estos cambios drásticos, vistos desde las comunidades actuales, tendrán que ser analizados en función de las formas antiguas. Habrá que preguntarse qué diferencias se han introducido en la vida social con el abandono de la actividad pesquera que han resentido los pueblos de lancheros. Un ejemplo: hasta hace poco existió el cargo de "pescador" en algunos pueblos ribereños, como en los de Palopó y Santiago; de su finitud está el testimonio de Douglas que muestra eI deterioro de una jerarquía social, que tuvo un lugar destacado en la vida civil y religiosa de la comunidad (SISG, Ob. cit., 261) :

El cargo de "pescador" fue suprimido en 1964 a consecuencia de la incapacidad del pueblo para justificar la necesidad del servicio. Este cargo tenía consigo el deber de conservar la canoa municipal para servicios en el lago. Estos servicios comprendían la provisión de transporte para los funcionarios del pueblo que controlaban la pesca, descubrir y trasladar a las personas ahogadas 
en el lago y conducir el correo. Con la merma de la pesca, el servicio de un peatón correo entre San Lucas y Santiago y el poco uso del transporte acuático de parte de los funcionarios del pueblo, hubo poca justificación para pedir su tiempo por un año a una persona.

¿Cuál sería la antigüedad de este cargo, tan en contacto íntimo con las aguas? Nos hacemos la pregunta, porque al penetrar en la bibliografía sobre Atitlán uno piensa que va a encontrar una riqueza de actividades acuáticas de todo tipo, con el lago como una especie de santuario.

Pronto nos sorprenderemos de que algo tan sencillo, aparentemente lógico en tal medio, como el saber nadar, sea aquí negativo. Personalmente lo constatamos y McBryde (II: 297) se encontró con que, a excepción de los hombres de Santa Catarina y algunos pedranos, pocos habitantes del lago sabían nadar, por lo que al voltearse algún cayuco había usualmente ahogamientos. Hay casos extremos, como el de San Andrés Semetabaj, cuyos habitantes insisten, como sus antepasados, en ser refractarios a la pesca y la navegación, debido a cierto pavor que les ha infundido siempre el agua, y al viajar lo hacen de preferencia por tierra (Aguirre, 1950: $50)$.

Igual resulta con las creencias y relatos de tradición oral, en las que muy poco se ha recogido que tenga al lago como protagonista. Ni en el mundo anímico, ni en el sobrenatural; tampoco en las enfermedades y su curación, se ve su presencia que se imaginaría determinante (Mc Dougall, 1946: 156; 1955: 123; Búcaro Moraga, 1959; IIN, 1971; Shaw, 1972; Hurtado y Batz, 1975: 170; Zamora Acosta, (Ob. cit., 151; Neuenswander, 1977; Batz, 1980: 105; Tarn, 1984:401). No aparece en la religión nativa donde el agua es tema fundamental, con sus peticiones de lluvia puntuales en épocas de siembra, ya que éstas tienen lugar en cerros y cuevas asignados. Un caso ocurre cerca de Tzanjuyó, en una cueva del cerro al comienzo de la subida a Sololá, donde anualmente se hacen ceremonias propiciatorias para los cultivos, a pesar de la cercanía con uno de los centros comerciales más alterados por el turismo. Recuerdo la cueva con restos de armadillos sacrificados, que Lothrop fotografió en Chuitinamit (1933: 82). Tampoco en danzas propiciatorias de la cacería, como la del Venado de San Pedro La Laguna, participan las aguas del lago (Paret-Limardo, 1963: 47).

$\mathrm{Ni}$ en fechas cercanas a la Conquista, cuando se describe al ídolo principal de Atitlán, se logra percibir alguna relación espiritual con 





el lago (Acuña, Ob. cit., 86). De los sacrificios humanos en tiempos de la gentilidad, son otros los lugares donde tenían lugar; en los volcanes dice, dudando, el obispo Cortés y Larraz (Ob. cit., 279).

Respecto a ofrendas a las aguas, arrojadas desde canoas, contrasta la abundancia con que aparecen en otros lagos de altura, como Amatitlán, con la escasez de ejemplares encontrados en Atitlán (Hernández Pons, 1982: 179).

Cuando la evangelización buscaba reducir a poblados a los indígenas, remisos de entrar en contacto con los españoles, fueron las necesidades, las urgencias materiales, las que establecieron la relación, en la dispensa de refugio y alimento que las orillas del lago daban a la vida montarás (Vásquez, Ob. cit., 44):

Trabajaron incesantemente en el laborioso ministerio algunos días, teniendo en ellos pláticas y andando a pie muy malos caminos, cuestas, ensenadas y barrancas para sacar de los ancones de los cerros algunas de las innumerables gentes, que se habían retirado en aquellos sitios a vivir en grutas, cuevas y cavernas, teniendo para su sustento el marisco, que con abundancia les daba la laguna, y papas y raíces que conccían y son de mucho sustento, calabazas y otros alimentos conocidos, sin querer reducirse a poblado, por no hallarse otra vez expuestos a las escopetas.

El vínculo sigue siendo lo que el medio aporta a la vida doméstica, entre gente de economía muy precaria, y a las relaciones sociales que se dan en el tránsito de la vida lacustre. Las canoas indígenas continúan transportando devotos y mercancías a las fiestas patronales (Figura 22), o a la concurrida visita a San Simón -Maximón- de Santiago Atitlán (Figura 23). Así se ve en el estudio de Mendelson (1965) sobre este culto reciente, que ha ido cobrando importancia regional (Batz, Ob. cit., 105; Búcaro Moraga, 1979: 199; Molina y Carrodeguas, 1980: 250).

El lago ha sido escenario de algunos de los acontecimientos sociales más importantes, y en sus embarcaderos muchísimas veces se ha concentrado el común de los pueblos. Véase el trasfondo político en la bienvenida que recibió el fraile viajero Alonso Ponce, con ceremonial y protocolo que quizá estaría repitiendo una forma antigua de hacer estallar el júbilo colectivo (Ciudad Real, Ob. cit., 19):

Luego, pues, como el padre comisario llegó a dicha laguna, pasando el pueblo de San Jorge, que ya amanecía, se embarcó con sus compañeros en las dichas canoas, y con muchos indios remeros y muy buen tiempo comenzó su navegación, y andadas dos leguas y media de travesía le salieron a recibir otras tres canoas 
de Atitlán en que iban muchos indios con trompetas y chirimías con que le regocijaron e hicieron fiesta Caminaron así todas las canoas otra legua cerca de tierra y pasando por entre las dos islas arriba dichas, llegaron a la playa y puerto de Atitlán, donde estaba el corregidor de aquella comarca y otros muchos españoles con todos los indios del pueblo aguardando al padre comisario, el cual saltó en tierra y de allí le acompañarof todos hasta el convento que no está lejos, con mucho ruido y fiesta de dảnzas y un mitote de muchos indios, muy vestidos con mucha y muy buena plumería. Hubo también representaciones de los naturales en su lengua, y bailaron y danzaron unos muchachos indios bailes y dạnzas a lo español, últimamente fue recibido el padre comisario por los frailes y luego dijo miśsa.

Siglos después, un recibimiento semejante le fue tributado al general Jorge Ubico cuando llegó de gira presidencial (Figura 24), escoltado por cayucos y principales; ocasión aprovechada por el infalible dictador para explicarles a los navegantes indígenas las ventajas de unas adaptaciones de su inventiva; una vela triangular y un flotador, que por supuesto pronto olvidaron (Hernández de León, 1943: 419).

Muchos más aspectos de la vida de estas comunidades podrían tratarse, en la búsqueda de las rešpuestas del hombre atiteco a lo que la naturaleza lacustre le ha ofrecido en el tiempo; desde $q$ que el más antiguo de todos lo descubrió, sorprendido por la transparencia del viento, hasta hoy; cuando hay que luehar y huir a través del lago, de las amenazas que traen de afuera los soldados y los depredadores.*

- En los últimos años, la vida atitleca es parte de úna violencia nacional, caracterizada por la represión oficial sobre las comunidades indígenas. También es diferente la respuesta de las otrora "tranquilas" poblaciones un centenar de guerrilleros ocuparon militarmente el 25 de enero - 1985- la cabecera municipal de Santiago Atitlán; el 4 de febrero fue emboscado un convoy del ejército entre los volcanes Tolimán y Atitlấn; una lancha patrullera con 20 efectivos fue hundida el 11 de febrero; numerosas bajas y un helicóptero averiado fue el resultado de dos emboscadas sucesivas en Santiago Atitlán; llega artillería pesada y tropas de infantería a la zona; treinta y seis pérdidas sufre el ejército, que en represalia incendió las montañas de Cabeza de Burro; más de diez mil personas salieron a las calles de San Pedro La Laguna en protesta por el asesinato cometido por los soldados, en las personas de dos indígenas torturados, uno de ellos anciaho principal; cinco campesinos de Santiago Atitlán fueron secuestrados por soldados vestidos de civil; ORPA - Organización del Pueblo en Armas -informa de sus

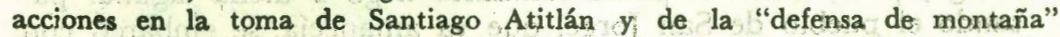
contra el ejército en las faldas del volcán; rechazo a columna del ejército en Parraxquín, San Pedro La Laguna. (ENFOPRENSA, Información de Guatemala, Números 109, 112, 114, 118, 122, febrero a mayo de 1985; ORPA, n. 2, información bimensual, marzo-abril, 1985). 


\section{BIBLIOGRAFIA}

ACUNA, RENE (editor)

1982 Relaciones geográficas del siglo XVI: Guatemala, Serie Antropológica, v. 45, Instituto de Investigaciones Antropológicas, UNAM, México.

ASGH

1936 Fotografía de ilustración general, en Anales de la Sociedad de Geografía e Historia dé Guatemala, v. XII, n. 4, Guate?BDFus mala, C.A.

AGUIRRE, LIVY

* Elita de la eterna primavera, Colección Contemporánea, Editorial del Ministerio de Educación Pública, Guatemala, Centro América.

BArz; Türs

1980 "Relatbs Tzutuhiles", Tradiciones de Guatemala, n. 14, Centro de Estudios Folklóricos, Universidad de San Carlos de Guatemala, C.A:

BorehgYi, Stephans DE

T959 "Cultura folk y cultura compleja en el Area Maya Meridio- cussidis nall", Cuadernos del Seminario de Integración Social Guatemalteca, No 5, Editorial del Ministerio de Educación Pública "José de Pineda Ibarra"y Guatemala, C.A.

Bucaro Moraga, Jaime ls mael

1959 Leyendas, cuentos, mitos y fábulas indigenas, edición mimeográfiea, Instituto Indigenista Nacional, Guatemala, C.A.

1979 "Semana Santa en Santiago Atitlán", Tradiciones de Guatemala, n 11-12, Centro de Estudios Folklóricos, Universidad de San Carlos de Guatemala, C.A.

Butler, James; Arnold, Dean A.

19.77 "Laiclasificación tzutujil del maíz en San Pedro La Laguna",

Estudios Cognitivos del Sur de Mesoamérica (editado por Helen
L. Neuenswander), Pub. 3, Instituto Lingúístico de Verano, Sil Museum of Anthropology, Dallas, Texas.

Carrasco, Pedro

6 1982 "El señorío tzutuhil de Atitlán en el siglo XVI", Sobre los Indios de Guatemala, Publicación No. 42, Seminario de Integración Social Guatemalteca, Ministerio de Educación, Guatemala, C.A.

Cuudad Real, Antonio de

1976 Relación breve y verdadera de algunas cosas de las muchas que sucedieron al padre fray Alonso Ponce en las provincias de la Nueva España, siendo comisario general de aquellas partes (edición de Josefina García Quintana y Víctor M. Castilio Farreras), 2 vols., Instituto de Investigaciones Históricas, UNAM, México

Cortés y Larraz, Pedro

isur 1958 Descripción geográfico-moral de la diócesis de Goathemala, tomo I, Bibiloteca "Goathemala", Sociedad de Geografía e Historia, Volumen XX, Guatemala, C.A.

Covarrubias, Miguet

1946 "El arte Olmeca o de la Venta", Cuadernos Americanos, V. XXVIII, n. 4, México. 
Cuevas, Mariano (editor)

1944 "Cartas del P. Bernabé Cobo, de la Compañía de Jesús", en Descripción de la Nueva España en el siglo XVII por el Padre Fray Antonio Vázquez de Espinosa y otros documentos del Siglo XVII, Editorial Porrúa, México.

DAvis, L. IRBY

1972 A field guide to the birds of Mexico an Central America, The John Fielding and Lois Lasater Maher Series, number one, University of Texas Press; Austin and London.

Fuentes y Guzmán, Francisco Antonio de

1933 Recordación Florida, discurso historial y demostración natural, material, militar y política del Reyno de Guatemala, tomo II, Biblioteca "Goathemala", Sociedad de Geografía e Historia, Volumen VII, Guatemala, C.A.

Healy, Paut F.

1980 "Archaeological Research in Belize", Mexico, Aktuelle Informatienen und Studien zu Mesoamerika, vol. II, n. 1, Austria.

Hernández de León, Federico

1943 Viajes presidenciales, t. II, Publicaciones del Partido Liberal Progresista, Guatemala, C.A.

Hernández Pons, Elsa

1982 "Algunas posibilidades de investigación arqueológica subacuática en el área maya meridional", Estudios de Cultura Maya, v. XIV, Centro de Estudios Mayas, UNAM, México.

1984 Investigaciones arqueológicas en el Valle del río Tulijá, Ta basco-Chiapas, Proyecto Tierras Bajas Noroccidentales, v. III, Centro de Estudios Mayas, UNAM, México.

Hinshaw, Robert E.

1975 Panajachel, A Guatemalan town in thirty-year perspective, University of Pittsburgh Press.

Hurtado, Juan José y Luis Raymundo Batz Solís

1975 "La posición de los characoteles en el mundo espiritual de San Pedro La Laguna", Tradiciones de Guatemala, n. 4, Centro de Estudios Folklóricos, Universidad de San Carlos de Guatemala.

IBARRA, JORGE A.

1959 Apuntes de Historia Natural y Mamíferos de Guatemala, Editorial del Ministerio de Educación Pública "José de Pineda Ibarra", Guatemala, C.A.

IIN

1971 "Aspectos de la medicina popular en el área rural de Guatemala", Guatemala Indigena, v. VI, n. 1, Instituto Indigenista Nacional, Guatemala, C.A.

1966 "Mercados regionales de Guatemala", Folklore de Guatemala, n. 2, Ministerio de Educación, Guatemala, C.A.

Lee, Thomas A.

1978 "The historical routes of Tabasco and northern Chiapas and their relationship to early cultural developments in central Chiapas", en Mesoamerican Comunication Routes and Cultural contacts (Thomas A. Lee Jr. y Carlos Navarrete, editores), Papers of the New World Archaeological Foundations, n. 40, NWAF, Brigham Young University, Provo, Utah.

Lothrop, SAMUET $\mathrm{K}$.

1929 a "Canoes of Lake Atitlan, Guatemala", Indian Notes, Vol. VI, 
no. 3, The Museum of the American Indian, Heye Foundation, New York.

$1929 \mathrm{~b}$ "The Henequen industry of San Pablo, Guatemala", Indian Notes, Vol. VI, no. 2, Museum of the American Indian, Heye Foundation, New York.

1933 Atitlan, an archaeological study of Ancient remains on the borders of Lake Atitlan, Guatemala, Carnegie Institution of Washington, Publication No. 44, Washington, D.C.

1936 Zacualpa, a study of ancient Quiché Artifacts, Publication 472, Carnegie Institution of Washington.

1952 "Zutugil dugout canoes", Notes of Middle American Archaeology and Ethnology, v. IV, n. 111, Carnegie Institution of Washington.

Manrique de Guzmán, Felipe

1935 "Relación Geográfica de la Alcaldía Mayor de Atitlán y Te. panatitlán", Boletín del Archivo General de Gobierno, t. I, n. 1, Secretaría de Gobernación y Justicia, Guatemala, G.A.

MaBryde, Félix Webster

1969 Geografía cultural e historia del suroeste de Guatemala, Publicación 24 y 25, Seminario de Integración Social Guatemalteca, 2 vols., Guatemala, C.A.

\section{Mc.Dougall, Elsie}

1946-48 "Eastern ceremonies at San Antonio Palopó, Guatemala", Notes of Middle American Archaeology and Ethnology, v. III, n. 81, Carnegie Institution of Washington.

1955 "Eastern ceremonies at Santiago Atitlan in 1930", Notes on Middle American Archaeology and Ethnology, v. V, n. 123, Carnegie Instiution of Washington.

Mendelson, E. Michael

1965 Los escáidalos de Maximón (un estudio sobre la religión y la visión del mundo en Santiago Atitlán), Publicación 19, Seminario de Integración Social Guatemalteca, Ministerio de Educación, Guatemala, C.A.

Molina, Diego; Ángeí A. Carrodeguas

1980 "El extraño culto de Maximón en Guatemala", Geomundo, año 4, n. 3, Editorial Samra, Venezuela.

Navarrete, Garlos

1973 "El sistema prehispánico de comunicaciones entre Chiapas y Tabasco (informe preliminar)", Anales de Antropología, UNAM, México.

1976 "Algunas influencias mexicanas en el Área Maya Meridional durante el Posclásico Tardío", Estudios de Cultura Náhuatl, n. 12, Instituto de Investigaciones Históricas, Universidad Nacional Autónoma de México.

Navarrete, Carlos y Thomas A. Lee Jr.

en proceso Quechua: un puerto fluvial sobre el Grijalva (Introducción a la arqueología zoque).

Nevenswander, Helen L. y Dean E. Arnold

1977 Estudios cognitivos del sur de Mesoamérica, Instituto Lingüístico de Verano, Pub. 3, Sil Museum of Anthropology, Dallas, Texas.

Ocaña, Diego dE

1953 "Descripción de la Laguna de Atitlán", Anales de la Sociedad de Geografía e Historia, t. IX, n. 3, Guatemala, C.A. 
Paret Limarioo Lise

1963 La danza del venado en Guatemala, Centro Editorial "José de Pineda Ibarra", Ministerio de Educación Públíca, Guatemala, C.A.

Quezada, Rigardo; Eula luna Rivas

1981 "La navegación entre los mayas: una actividad económica", Boletín de la Escuela de Giencias Antropológicas de la Universidad de Yucatán, nos. 50,51 , Mérida.

ReINA, RuBÉN E.

1966 "A peninsula that may have been an island, Tayasal, Peten, Guatemala", Expedition, v. 9, n. 1, The Bulletin of the University Museum University of Pennsylvania.

Santamaría, Francisco J.

1921 El provincialismo tabasqueño, t. Editorial Andrés Botas e Hijo, México.

SISG

1968 Los pueblos del Lago de Atitlán, Seminario de Integración Social Guatemalteca, no. 23, Tipografía Nacional, Guatemala C:A.

Serrano, Manuel

1970 El Lago de Atitlán, Colección de la Gultura de Occidente, Vo-

Shaw, Mary lumen no. 3, Tipografía Nacional, Guatemala, C.A.

1972 Según nuestros antepasados . (textos folklóricos de Guatemala y. Honduras), Instituto Lingüístico de Veranio, Guatemala, C.A.

Tharn, NaThaniel

1984 "Eating the fruic: sexual metaphor and initiation in Santiago Atitlan", Investigaciones Recientes en el Hreid. Maya XVII Mesa Redonda, Sociedad Mexicana de Estudios Antropológicos, San Cristóbal las Casas, del 21 al 27 de juntio de 1981, *. III, Chiapas.

TAx, SoL

1964 El capitalismo del centavo, Seminario le Infegración Social Guatemalteca, nos. 12 y 15, Ministerio de Educación Pública, Guatēmala, C.A.

VÁsquez, Francisco

1937 Crónica de la Provincia del Santísimo Nombre de Jesús de Guatemala, de la orden de N. seráfico Padre San Francisco én el Reino de la Nueva España, Biblioteca "Goathemala", v. XIV, Sociedad de Geografía e Historia, Guatemala, C.A.

1968 "Fragmentos de la Crónica de la Provinca del Santísimo Nombre de Jesús de Guatemala", Guatemala Indigena, v: IV, n. 1 (número dedicado a celebrar el cuatricentenario de la fundación de Sololá), Instituto Indigenista Nacional, Guatemala, C.A.).

VillagutierRe Soto-MAYOR

1933 Historia de la conquista de la Pravincia de El Itzd, Biblioteca "Goathemala", vol. IX, Sociedad de Geografia e Historia, Guatemala, C.A.

WEBSTER, HELEN T.

1963 "Tikal Graffiti", Expedition, v: 6, n. 1, The Bulletin of the University Museum, University of Pennsylvania. 


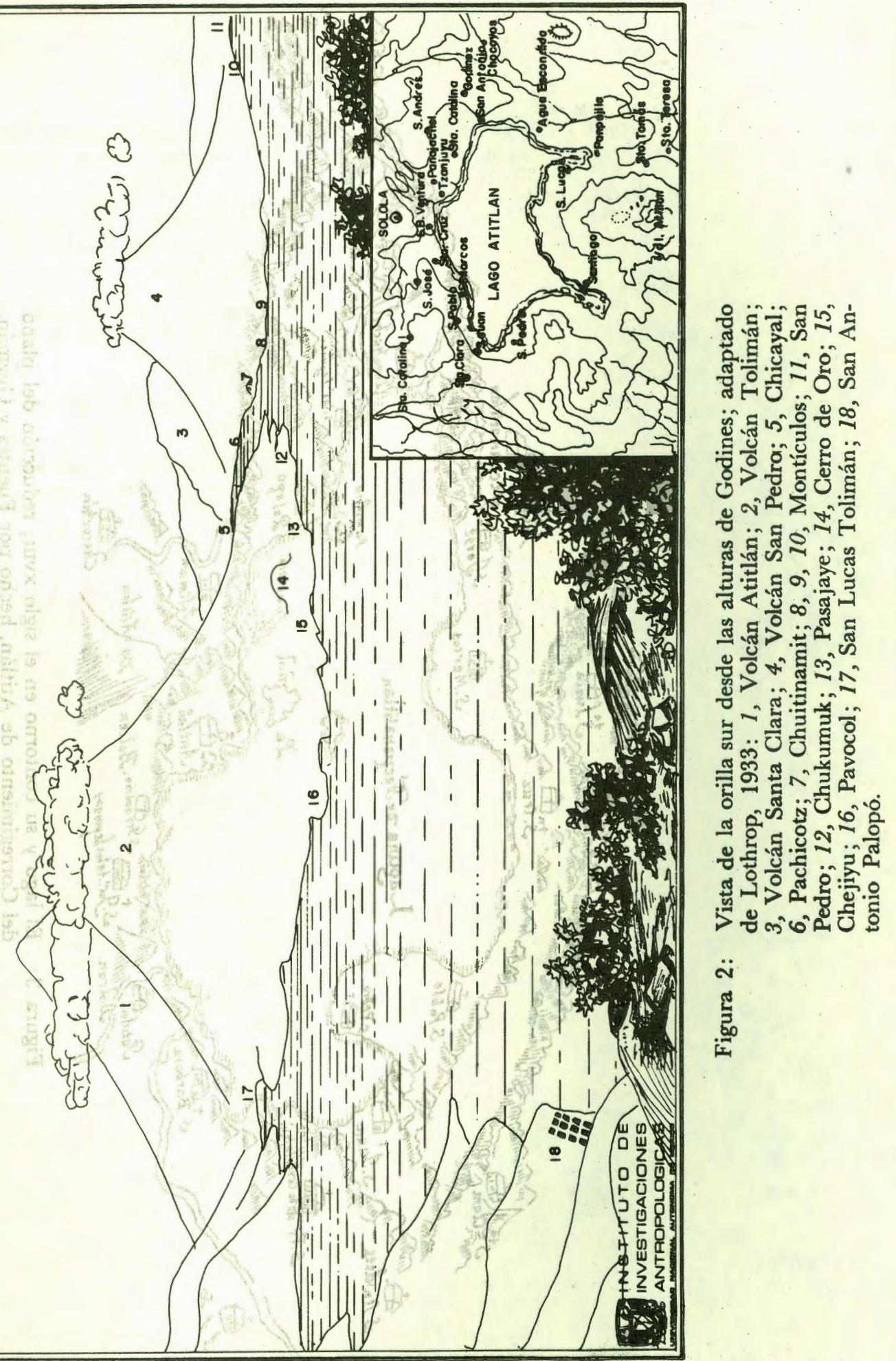




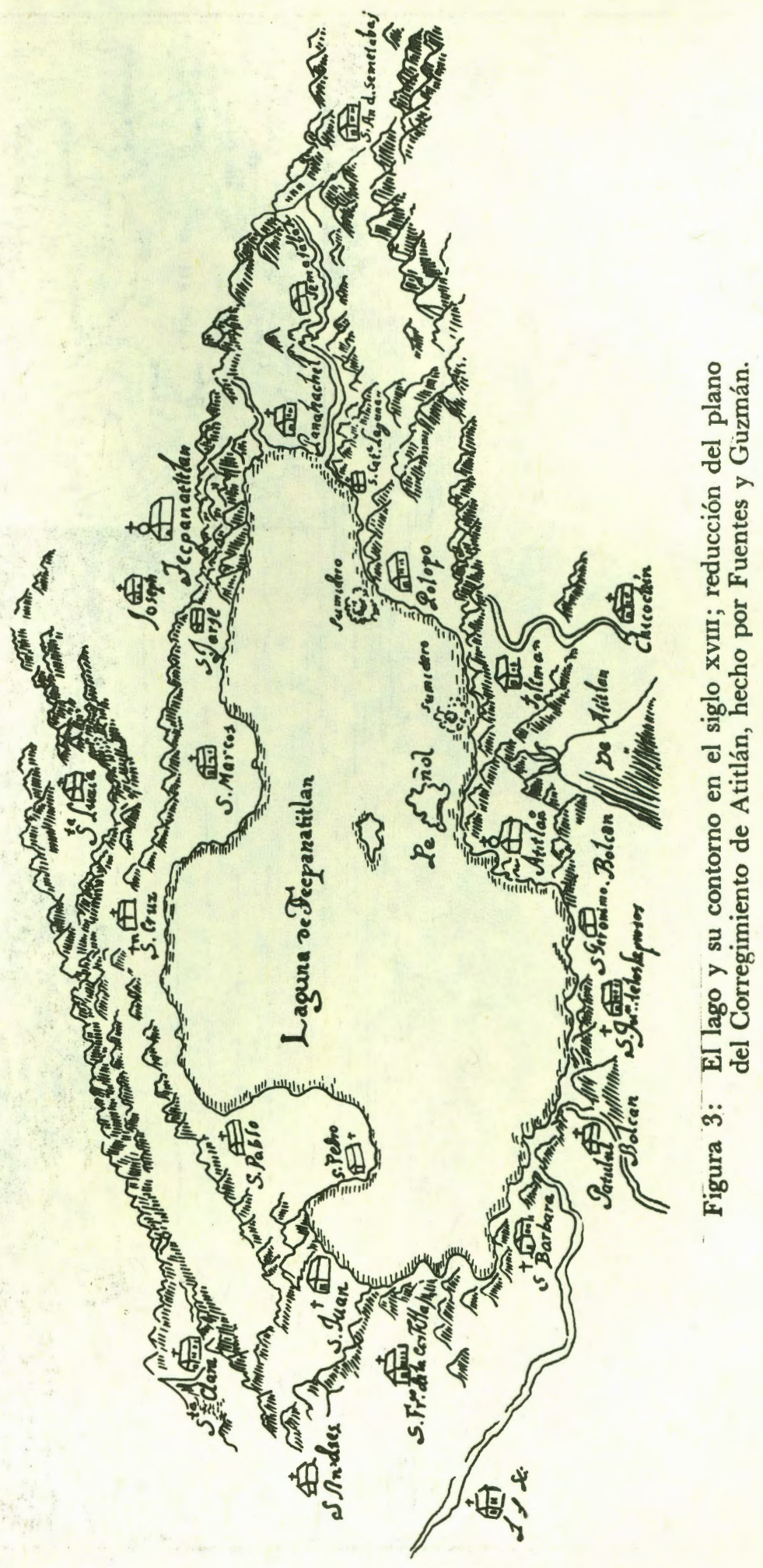



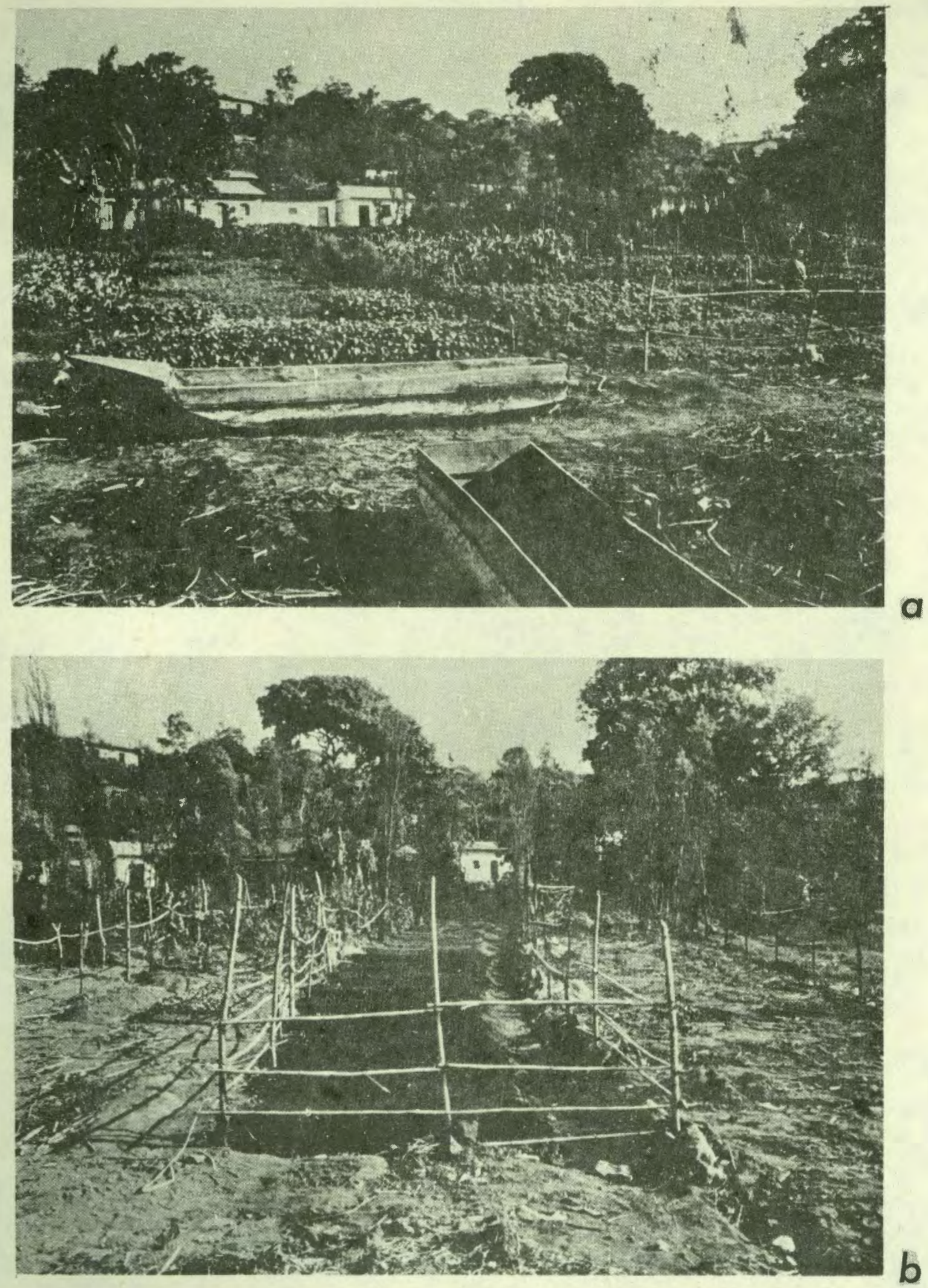

Figura 4: $a$, Siembras de legumbres en la playa de Santiago Atitlán; $b$, Sistema de camellones y canalización para riego desde el lago. 


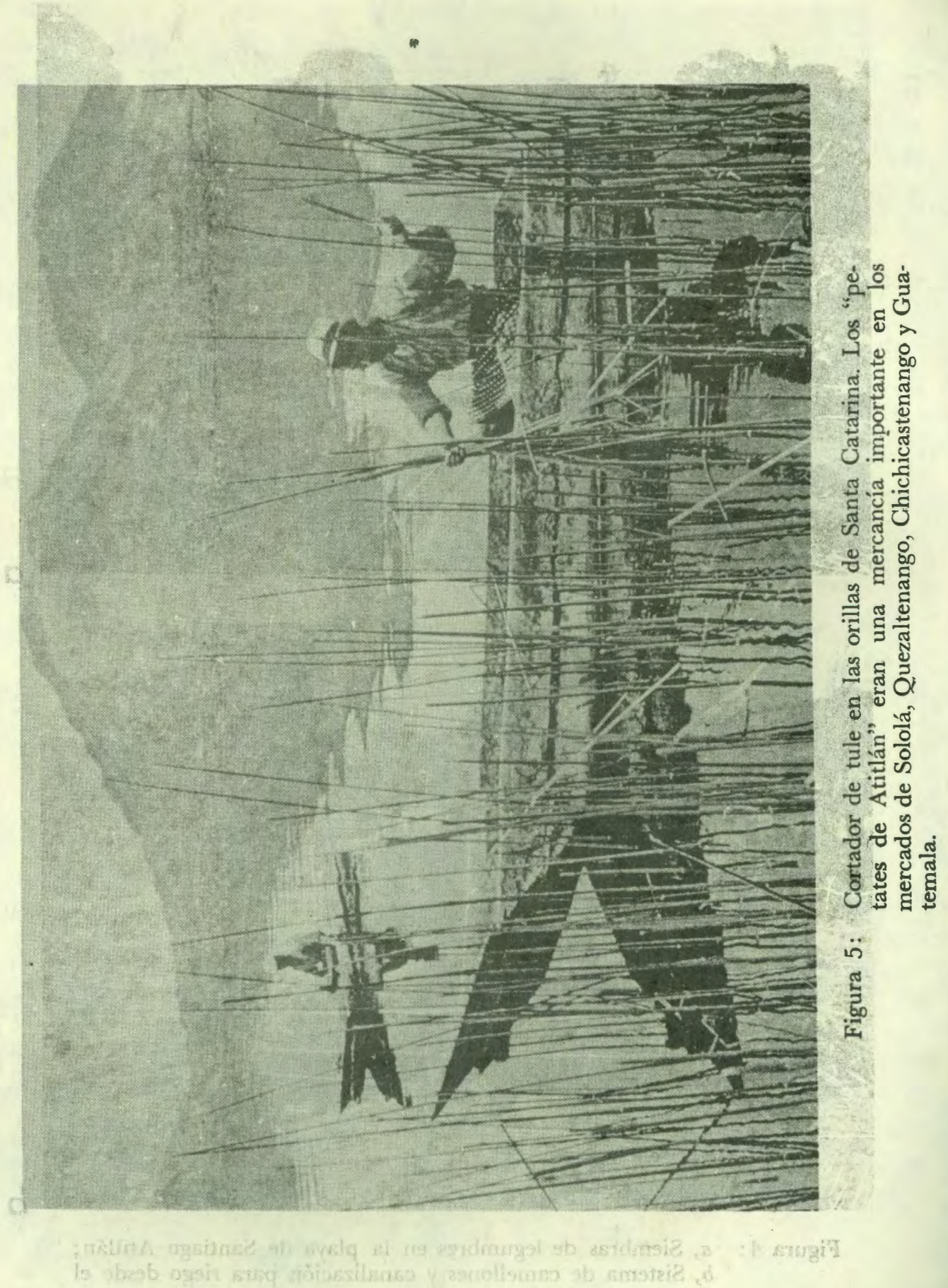




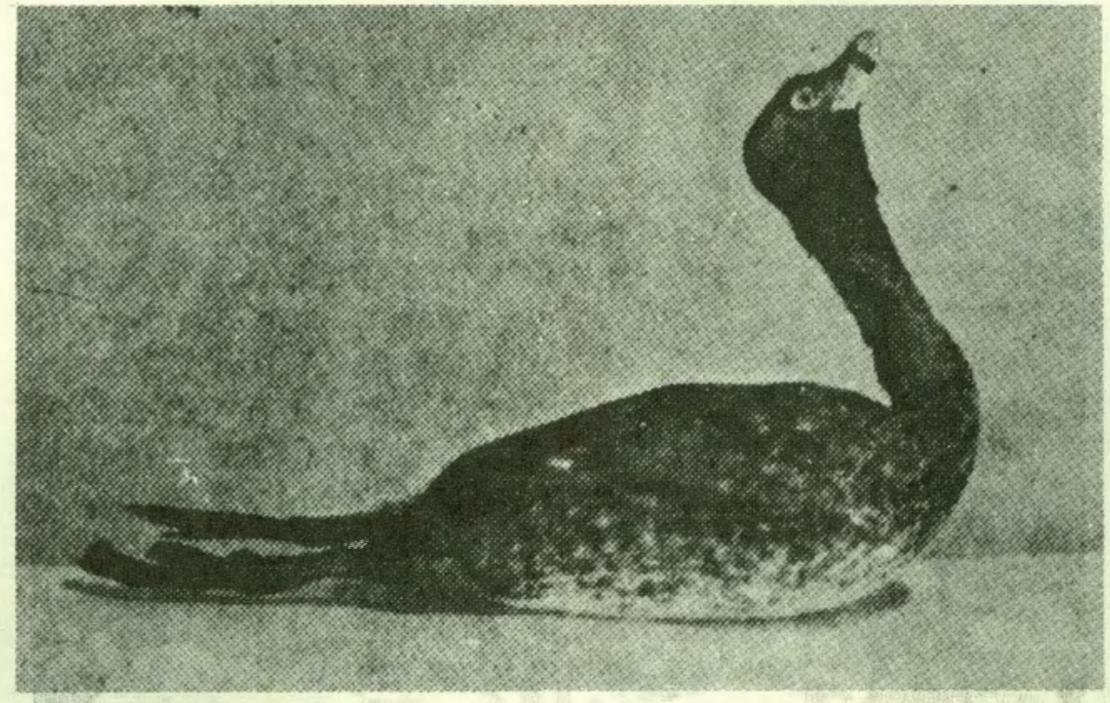

a

Figura 6: a, Pok, el pato zambullidor (según Serrano), tiene $37 \mathrm{~cm}$. de largo; $b$, Fragmento de vasija procedente de Panajachel, con los diseños en negro sobre blanco (Museo de Arqueología y Etnología de Guatemala).
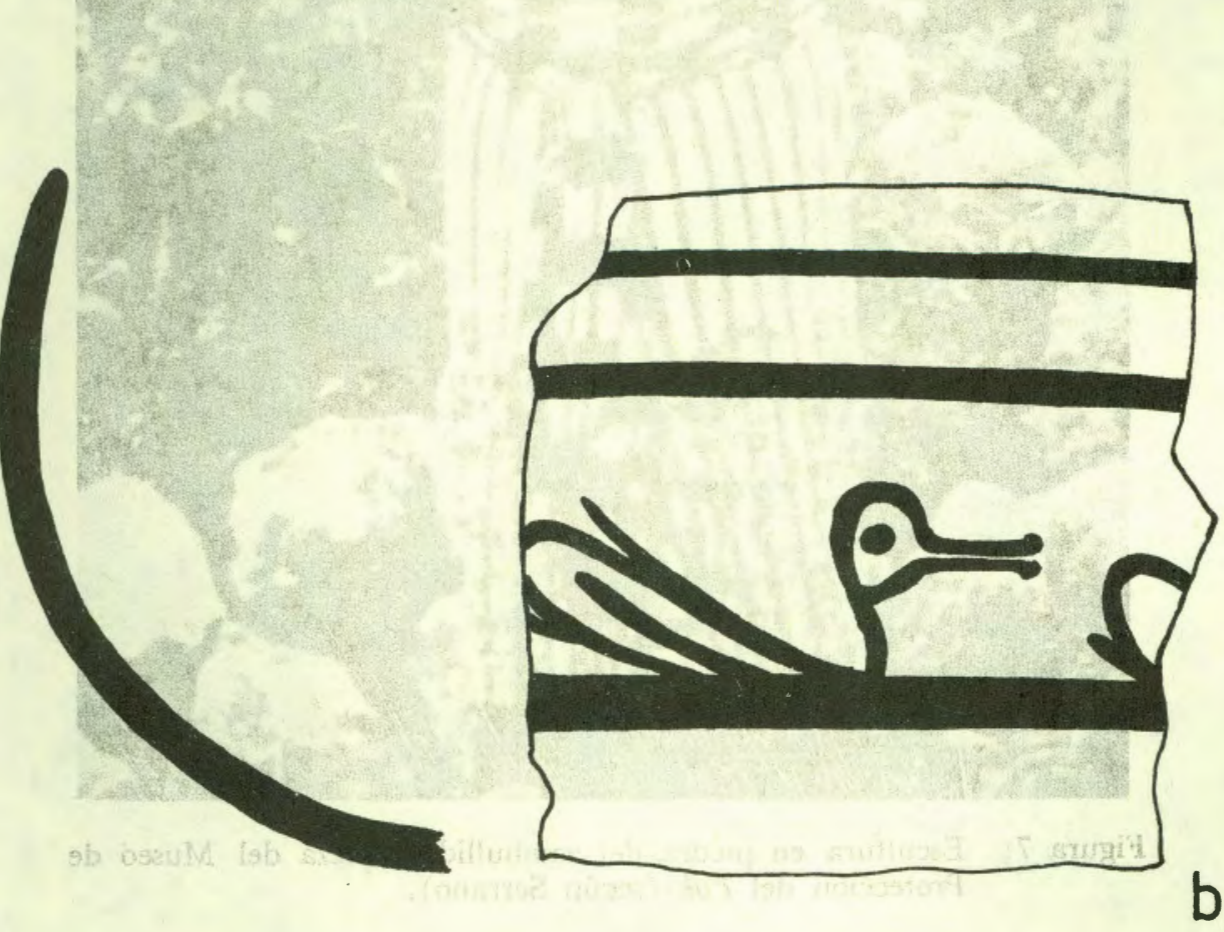


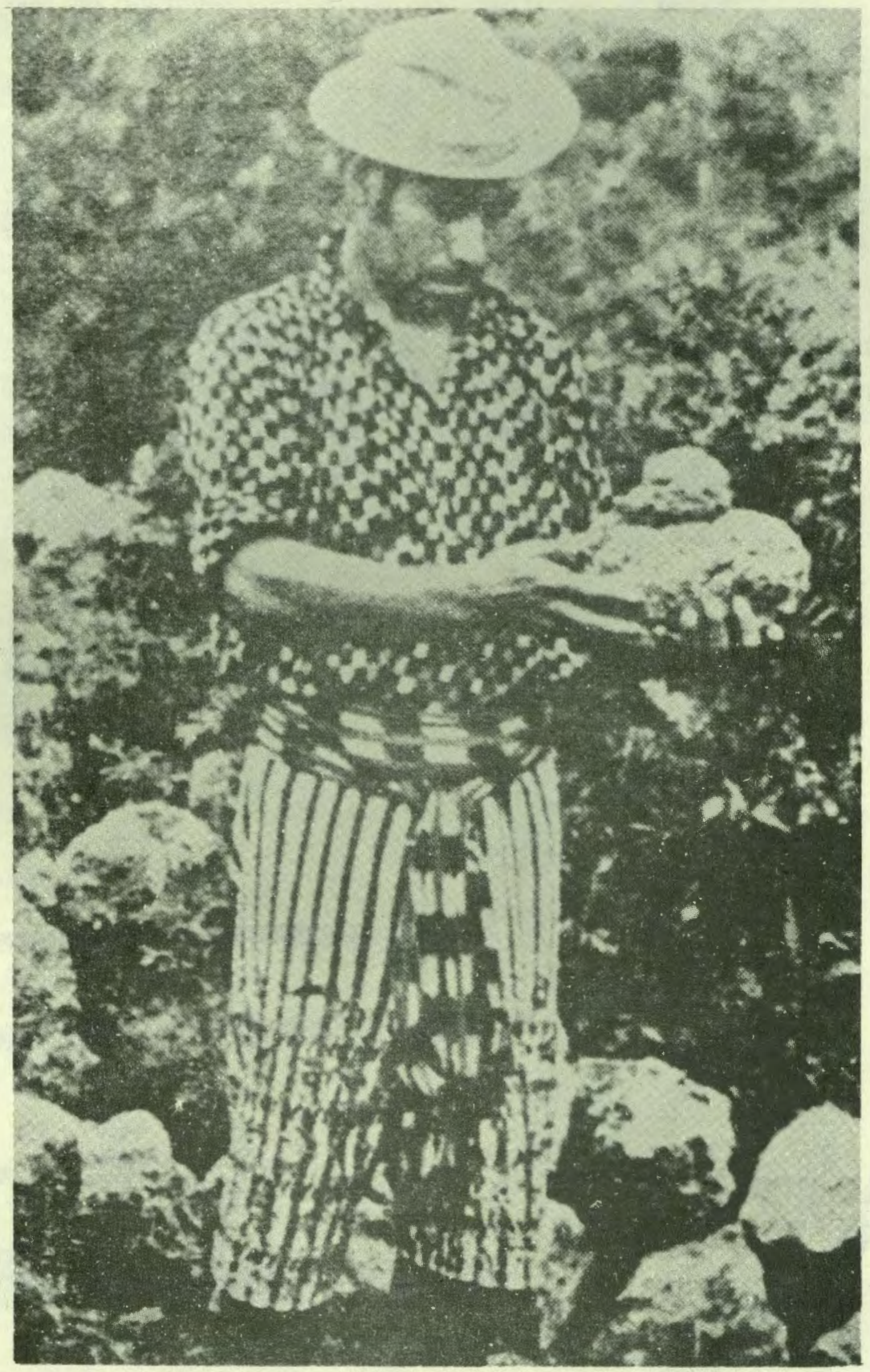

Figura 7: Escultura en piedra del zambullidor; pieza del Museo de Protección del Pok (según Serrano). 


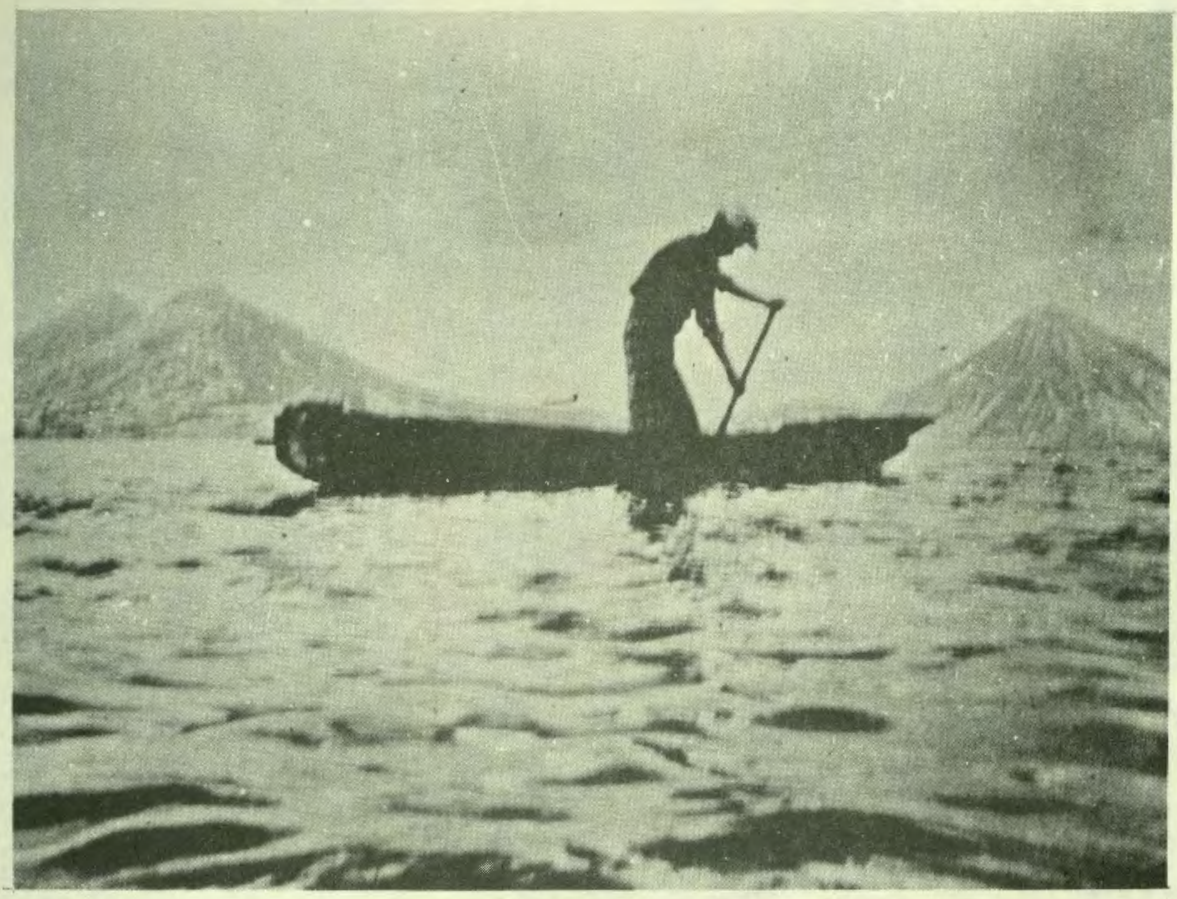

a

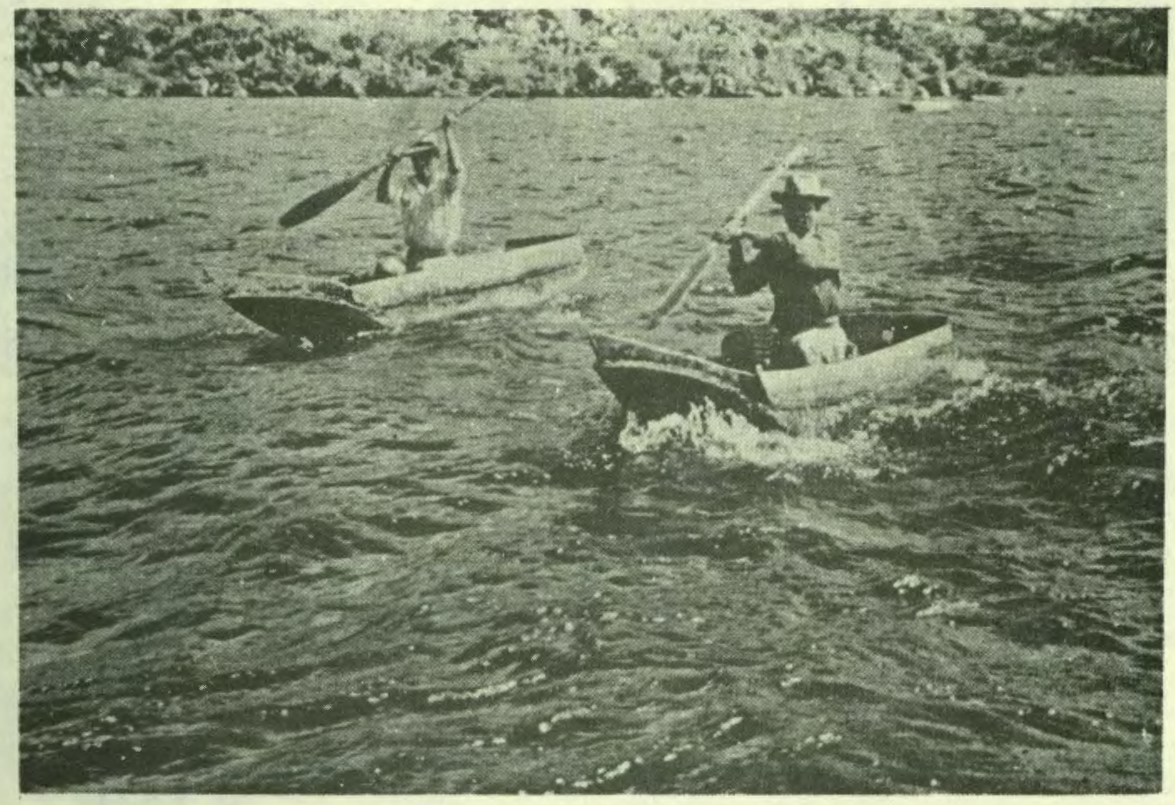

Figura 8: Dos formas de manejar una canoa: a, de pie, al estilo indígena tradicional; $b$, sentados sobre troncos livianos o pequeños banquillos no fijos. 


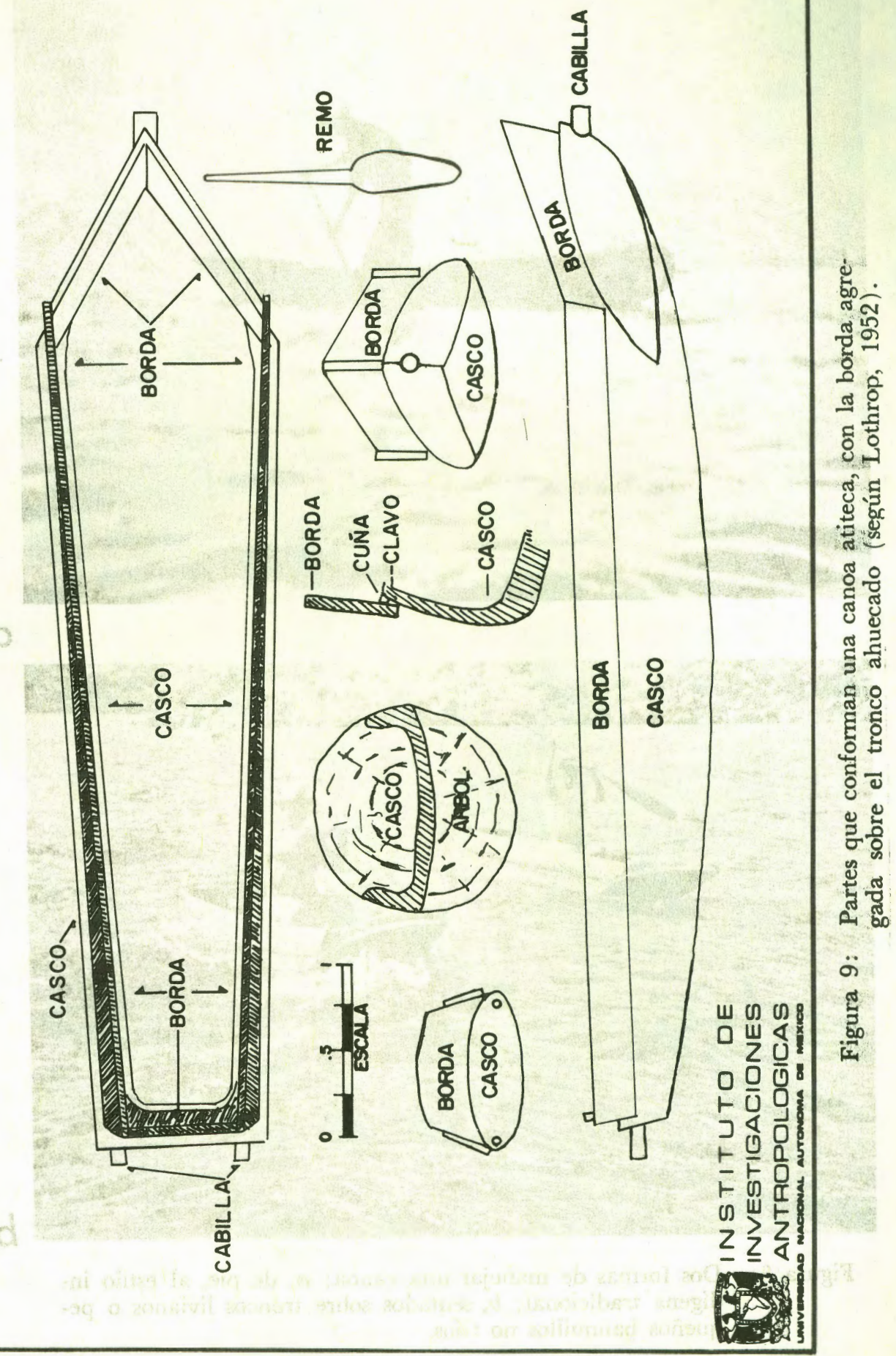



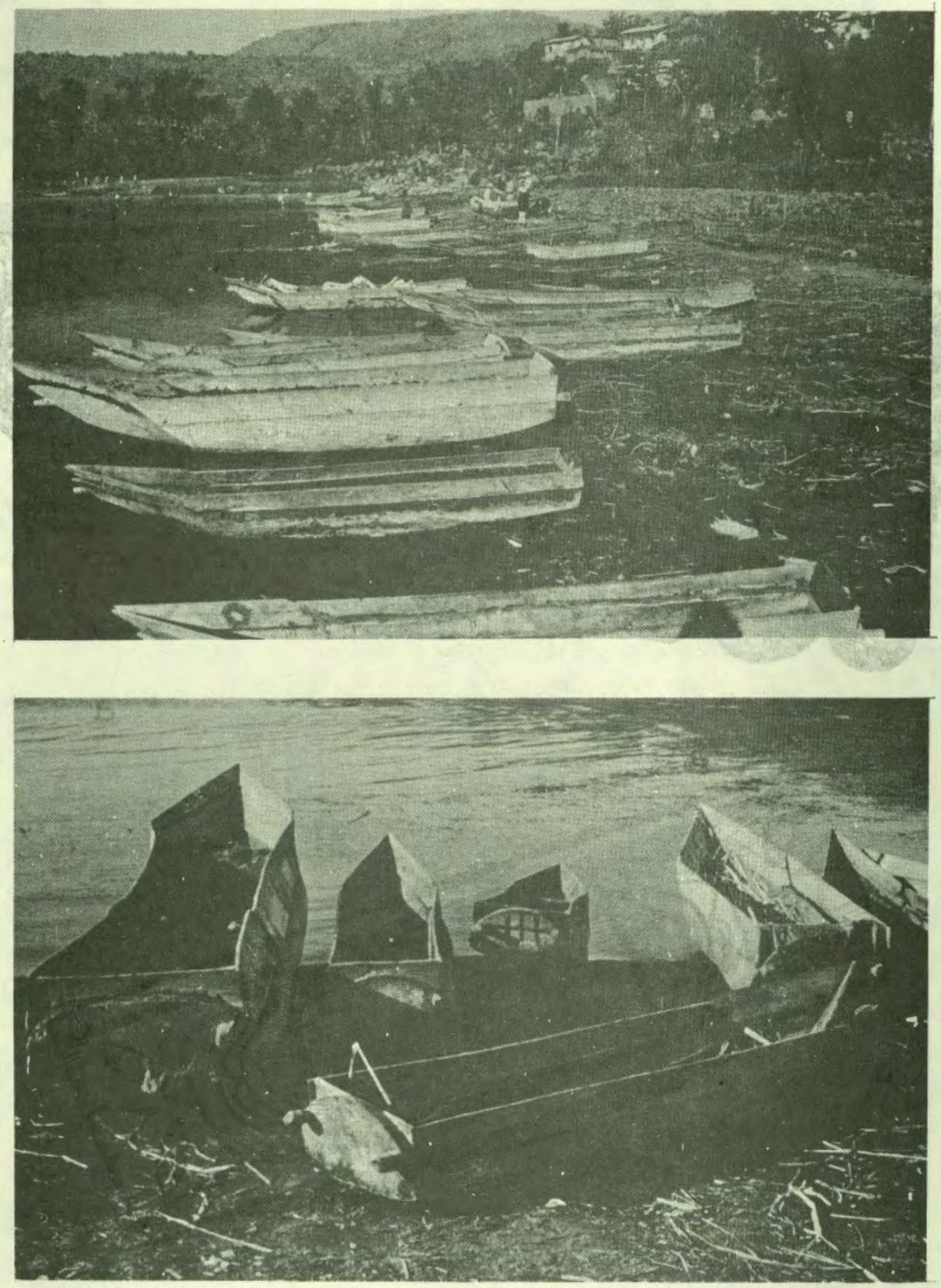

Figura 10: Canoas de diversos tamaños en Ta playa de Santiago Atitlán, donde se fabrican las mejores embarcaciones del lago, 1978. 


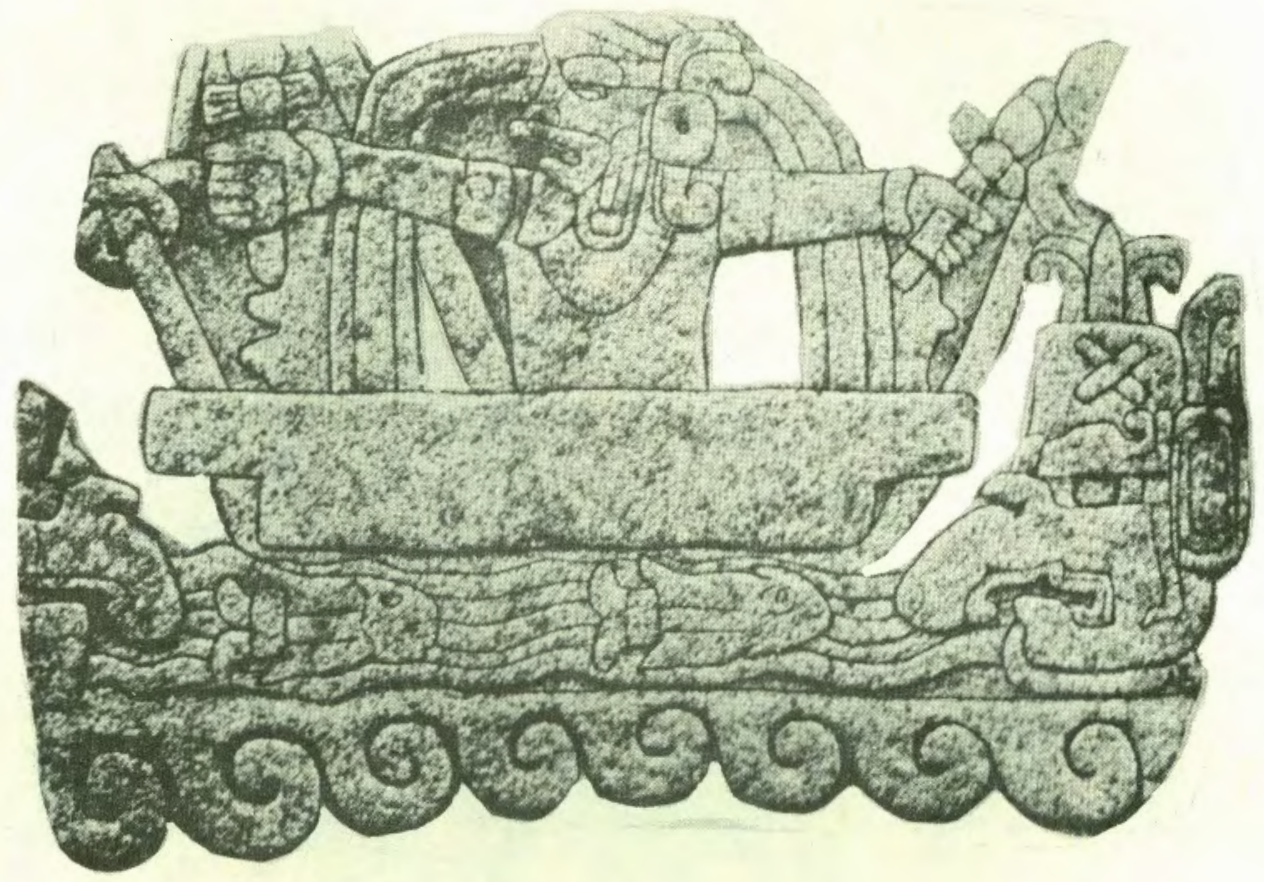

a

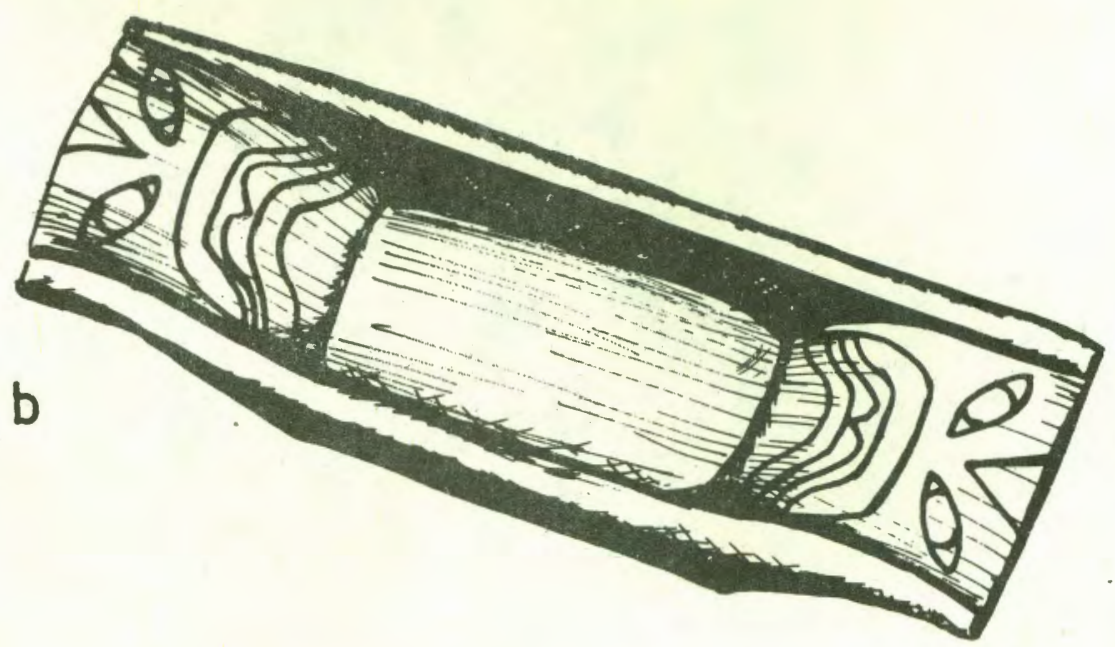

Figura 11: a, Estela 67 de Izapa, del Preclásico Superior, con una de las representaciones mesoamerícanas más antiguas; $b, \mathrm{Pe}-$ queña canoa olmeca de jade (Covarrubias, 1946: Fig. 21). 


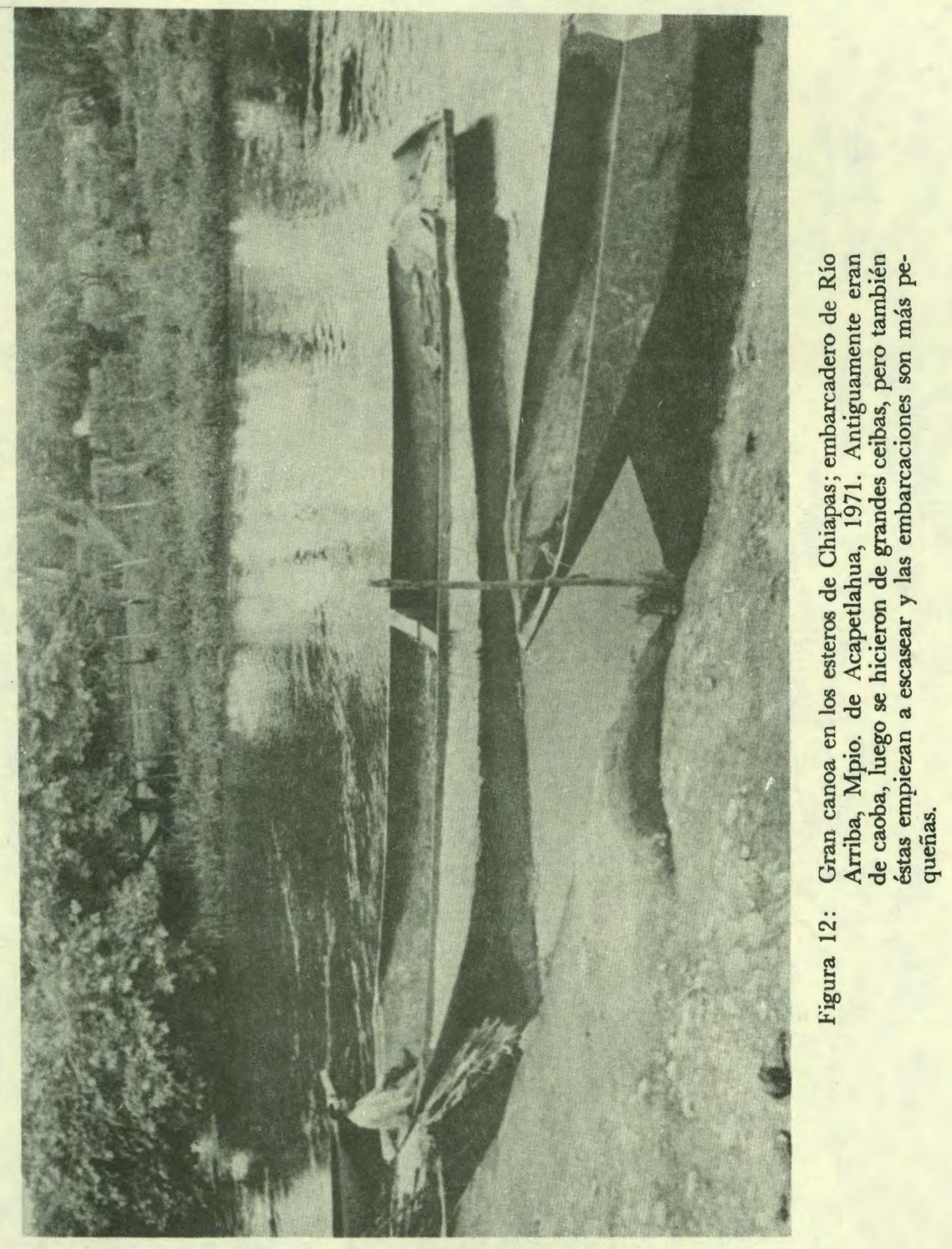



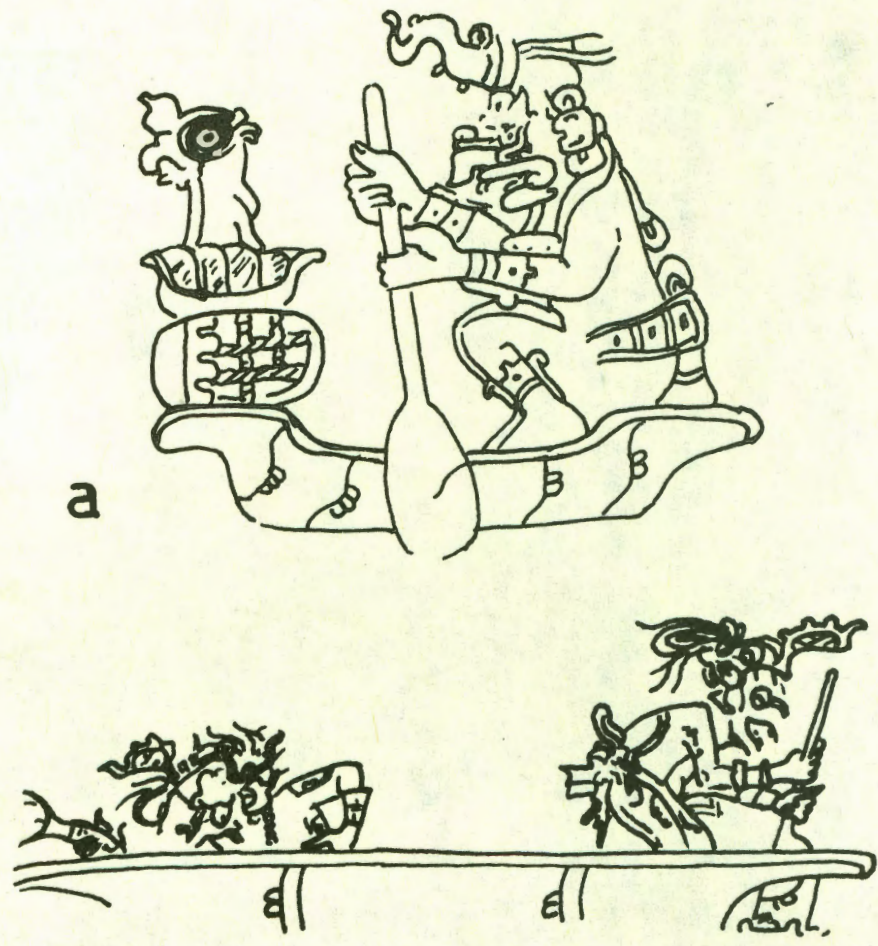

b

b

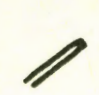

3)
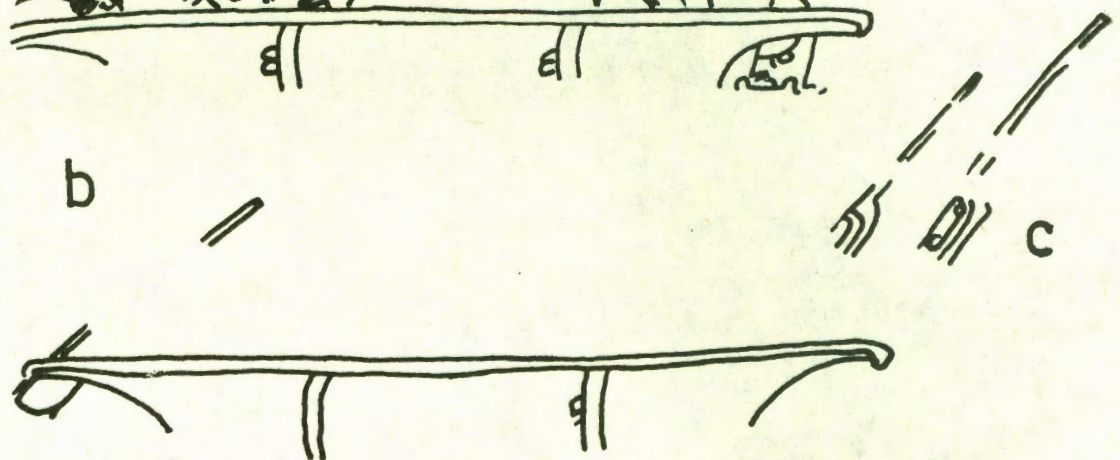

Figura 13: $a$, Canoa de la página 43 del Códice de Dresde; $b$, huesos labrados de la tumba del Templo I de Tikal; $c$, Tipo de remos en otros huesos de la misma tumba. 


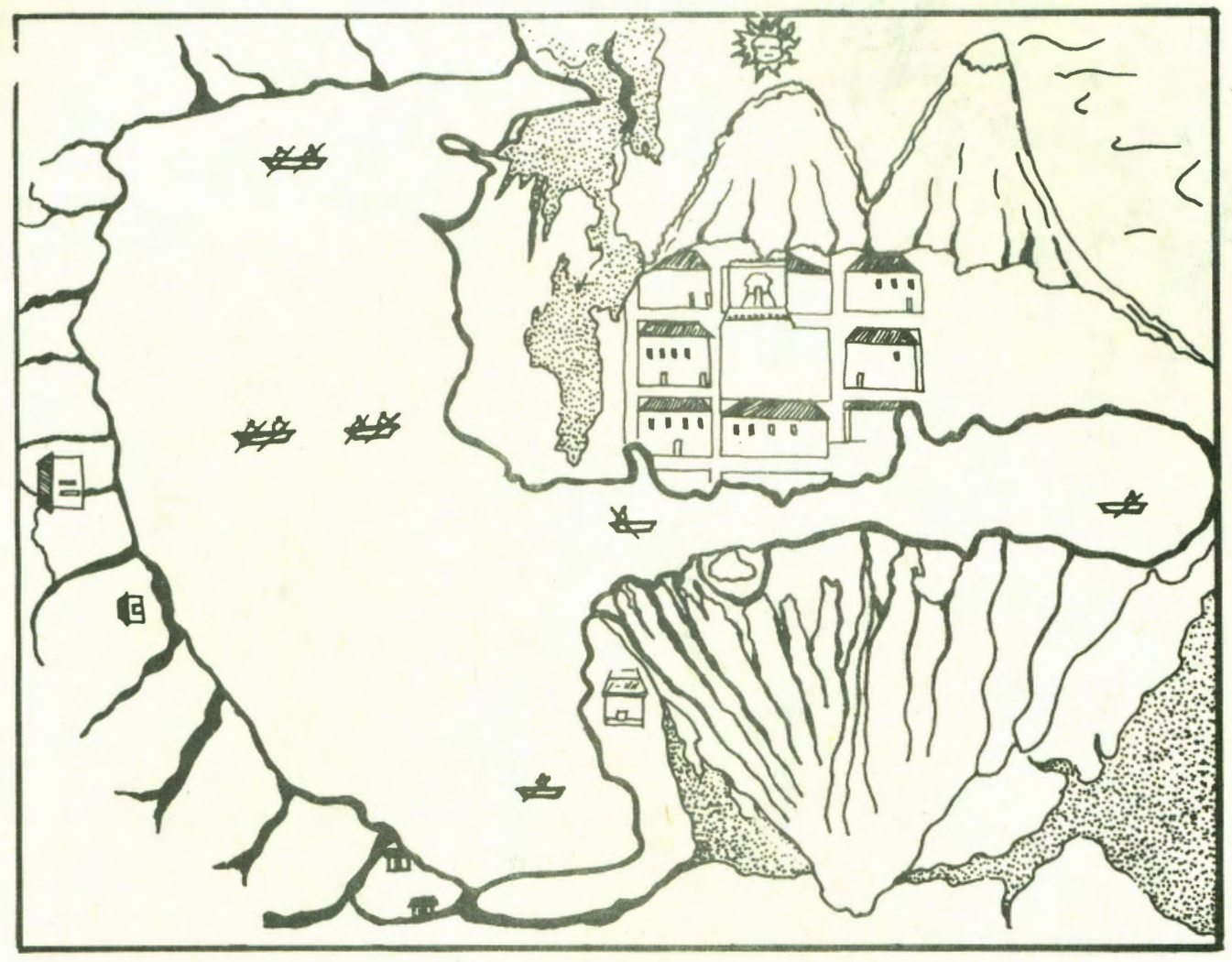

Figura 14. Versión esquematizada del mapa de la Relación de Santiago Atitlán, del siglo xvi, en la que hacemes resaltar las canoas. 

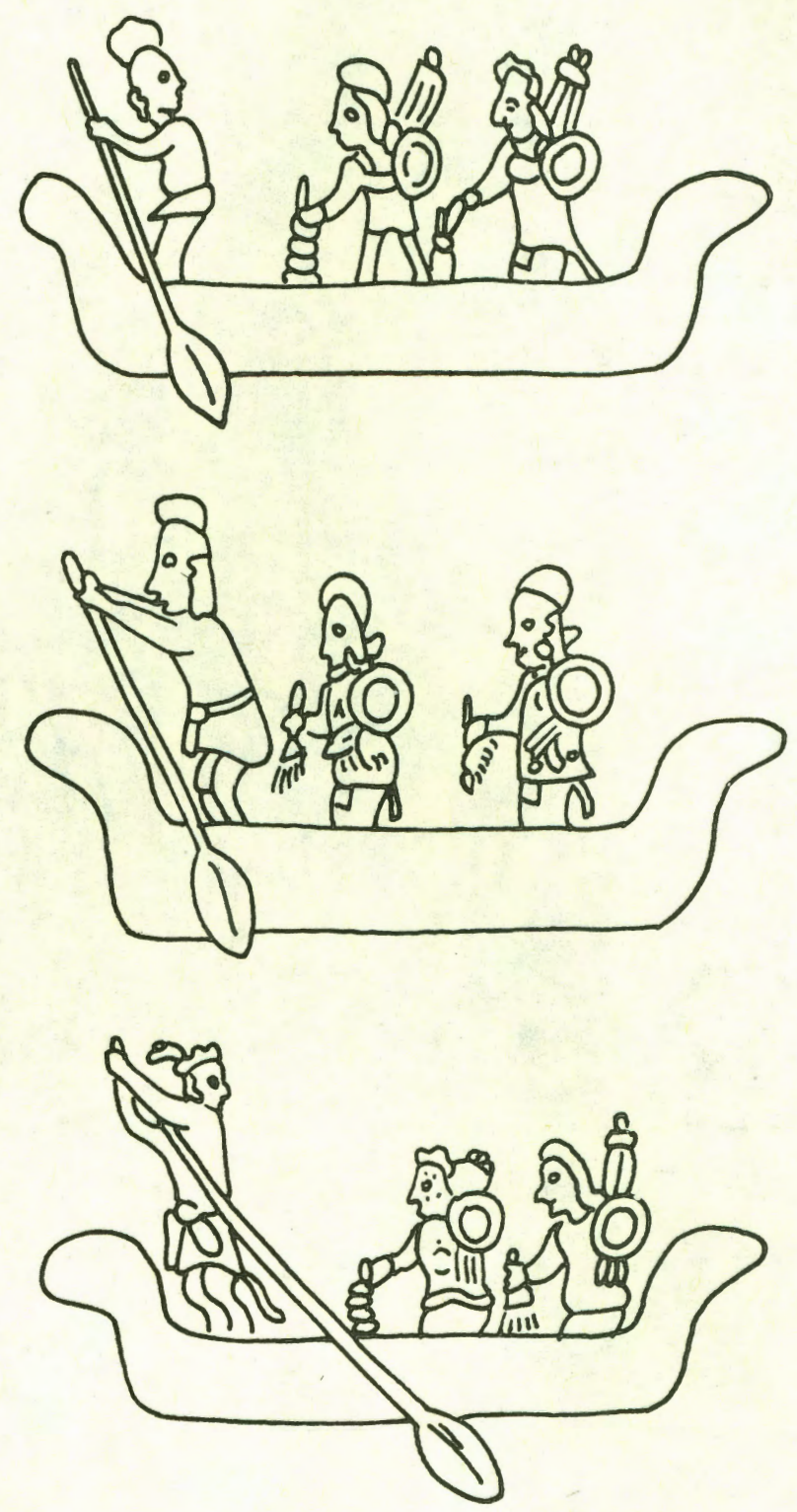

Figura 15: El boga y los pasajeros puestos de pie. Templo de los Guerreros, Chichén Itzá. 


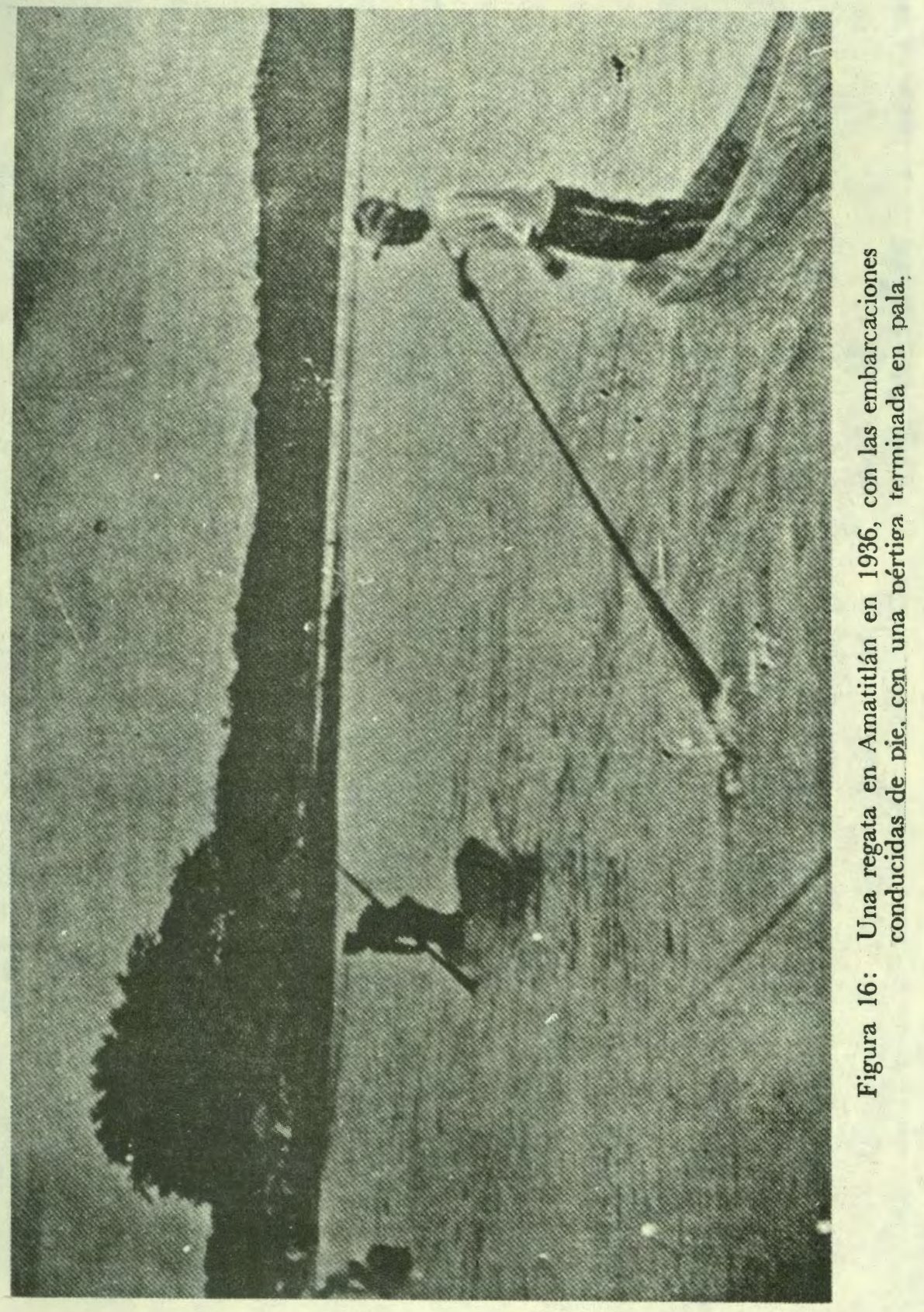



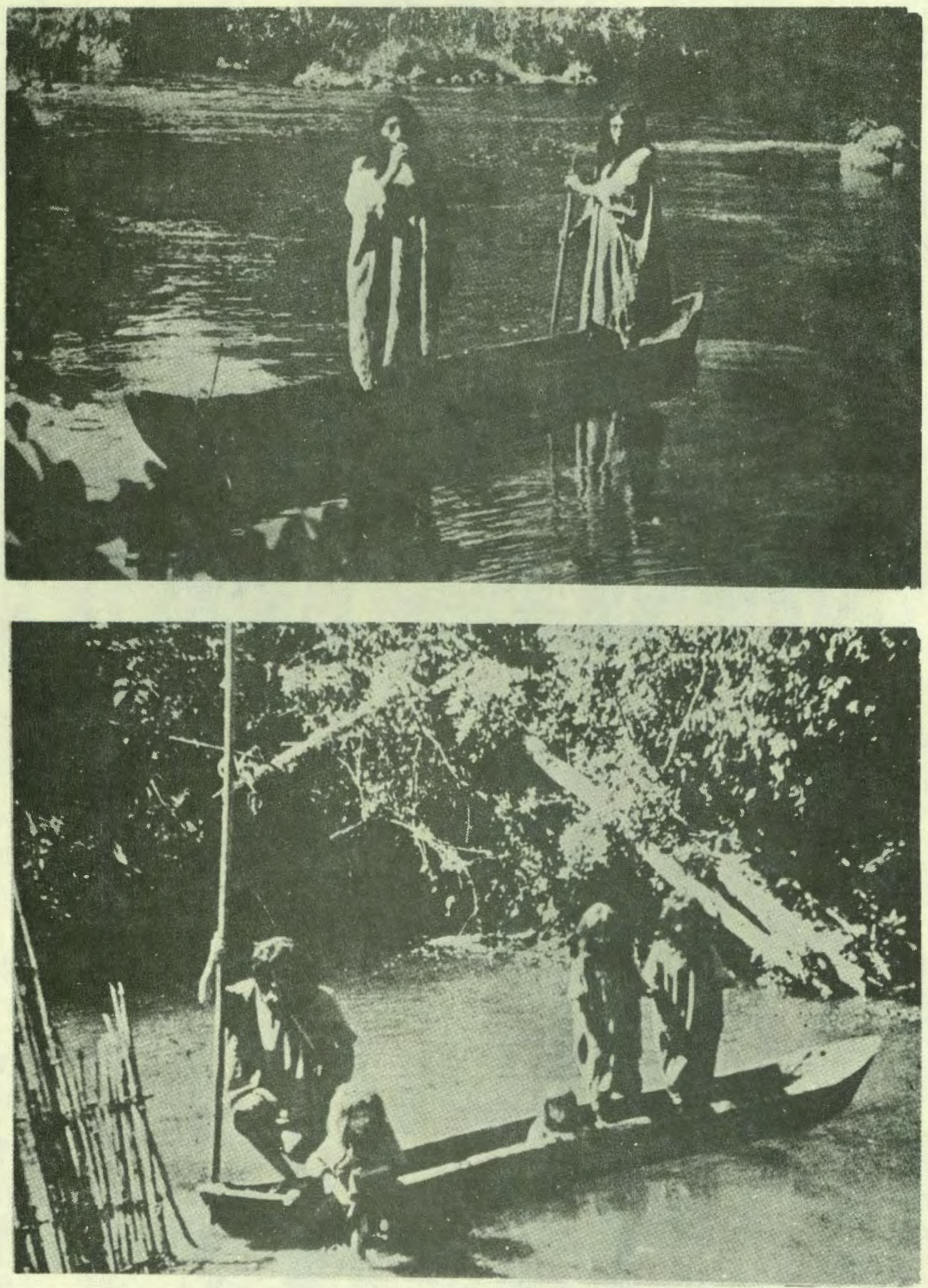

Figura 17: Dos fotografías de cayucos lacandones; el remo se sustituye, con una pértiga, 1940. 

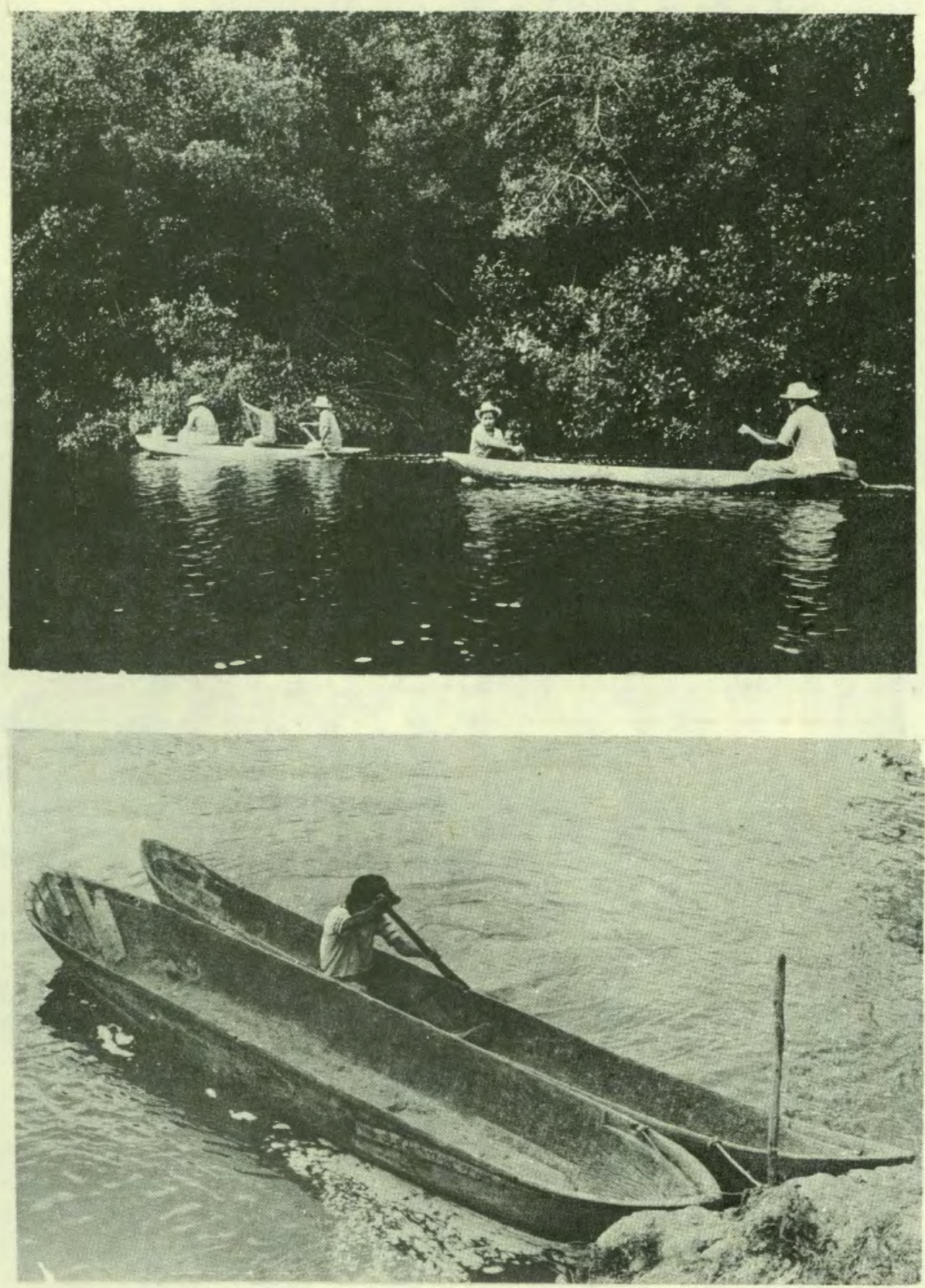

Figura 18: $a$, Cayucos en los esteros de Chiapas; $b$, Cayucos familiares en el Tuliiá. región de Salto de Agua, Chiapas. 

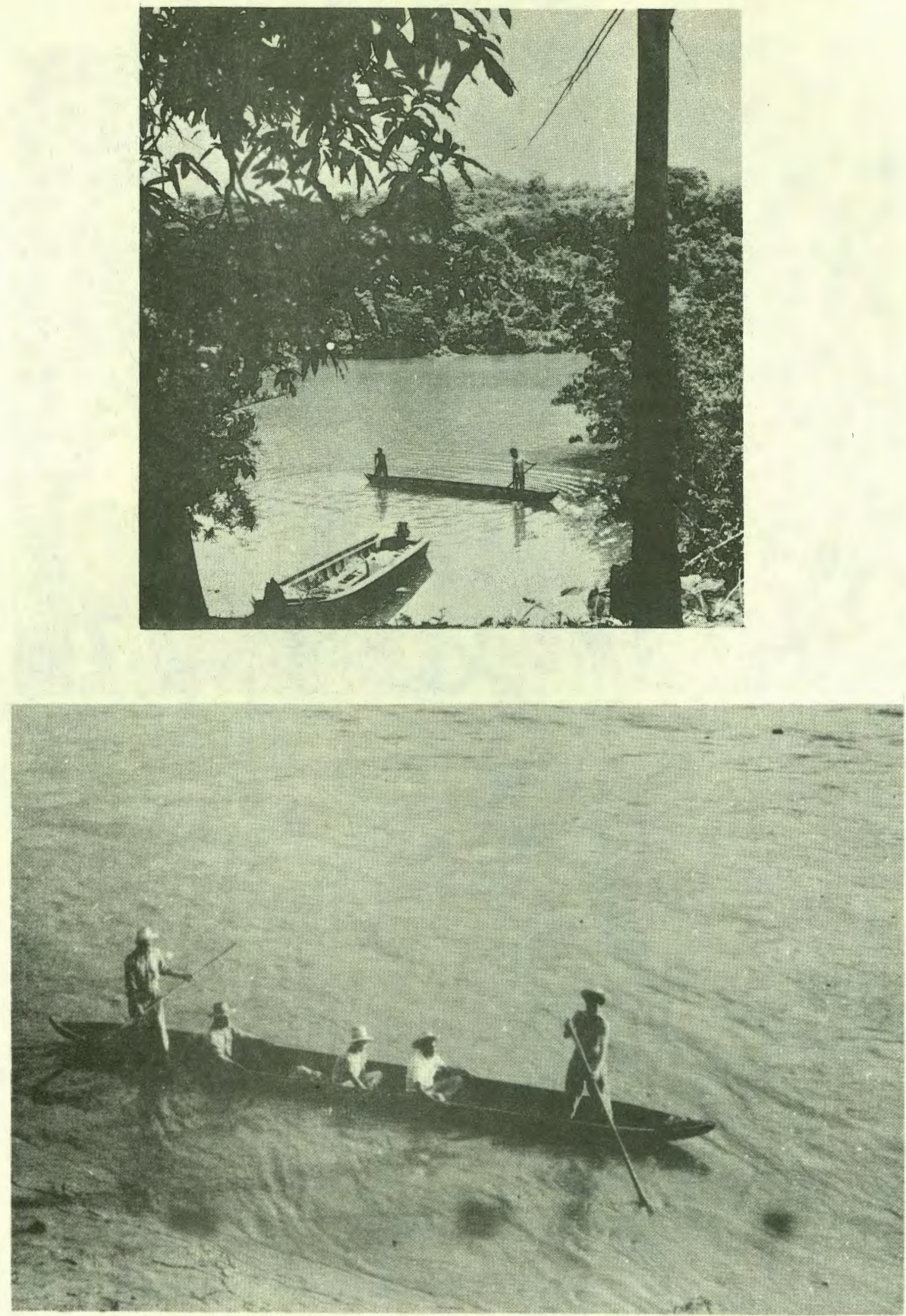

Figura 19: Cayucos con dos conductores en el Grijalva medio, tramo de San Isidro; Chiapas. 

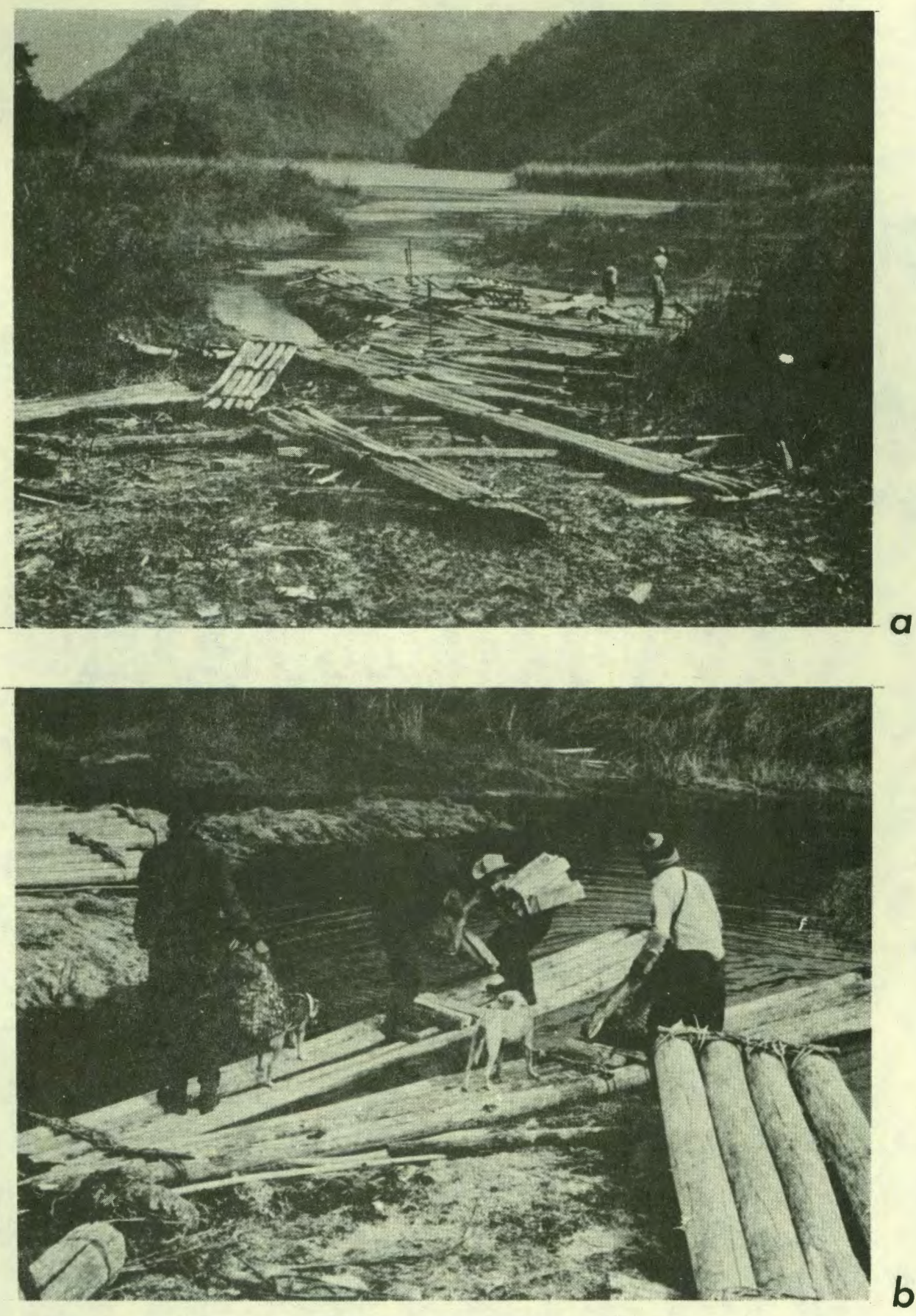

Figura 20: Laguna de Yolnajab, Huehuetenango, Guatemala: a, Embarcadero de balsas de Yalambojoch ; $b$, la carga se protege haciéndoles una cama de pequeños trozos. 


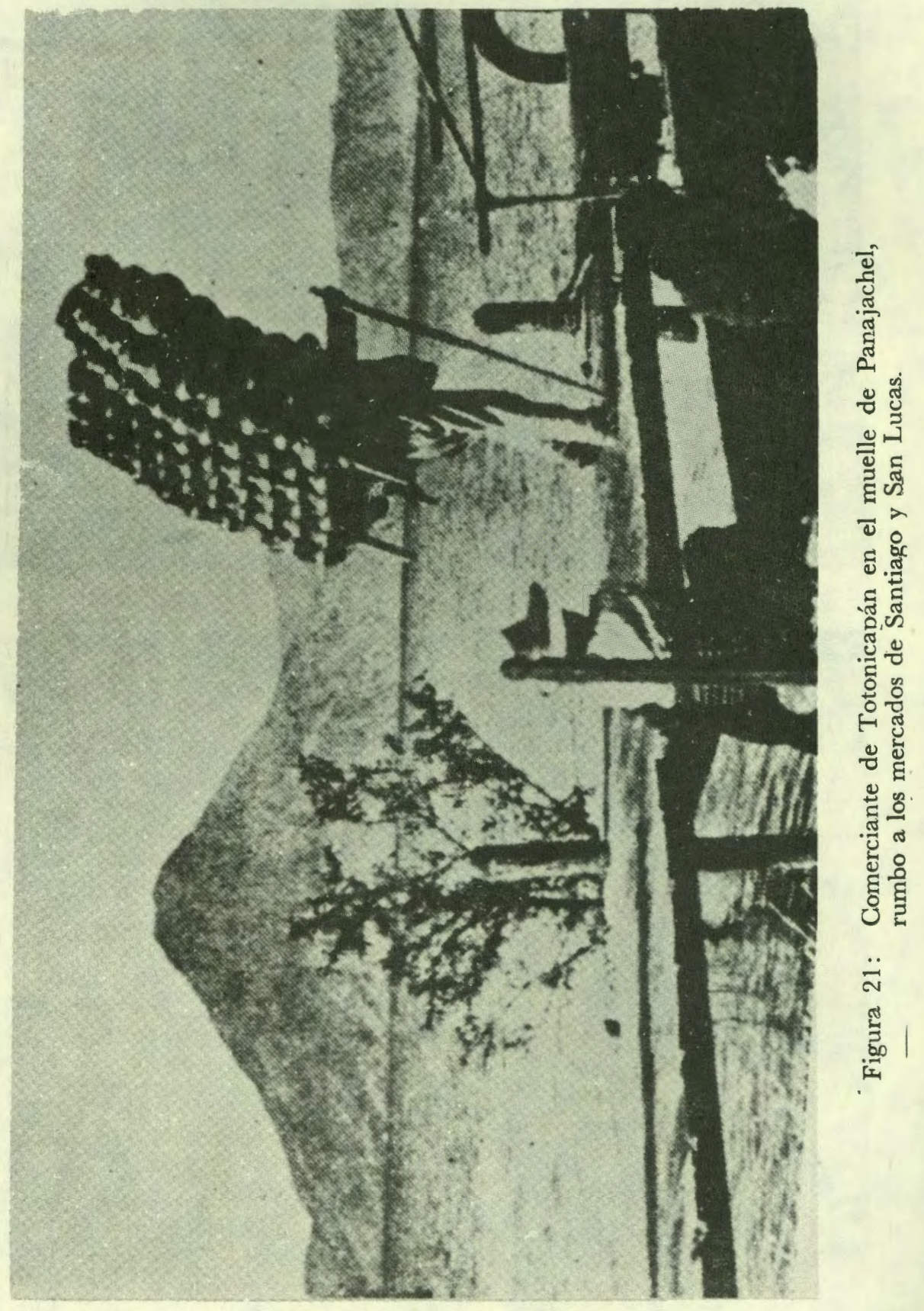




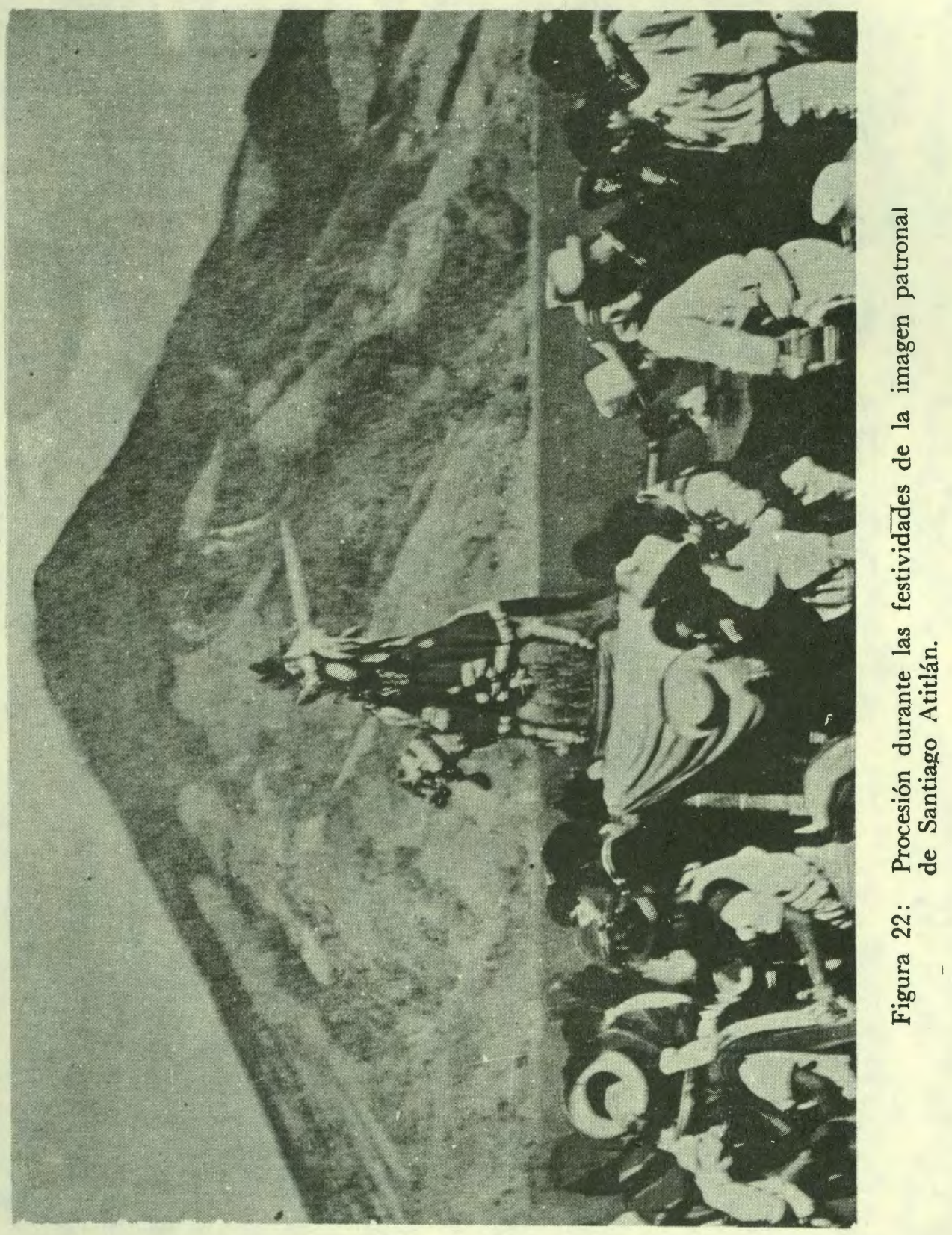




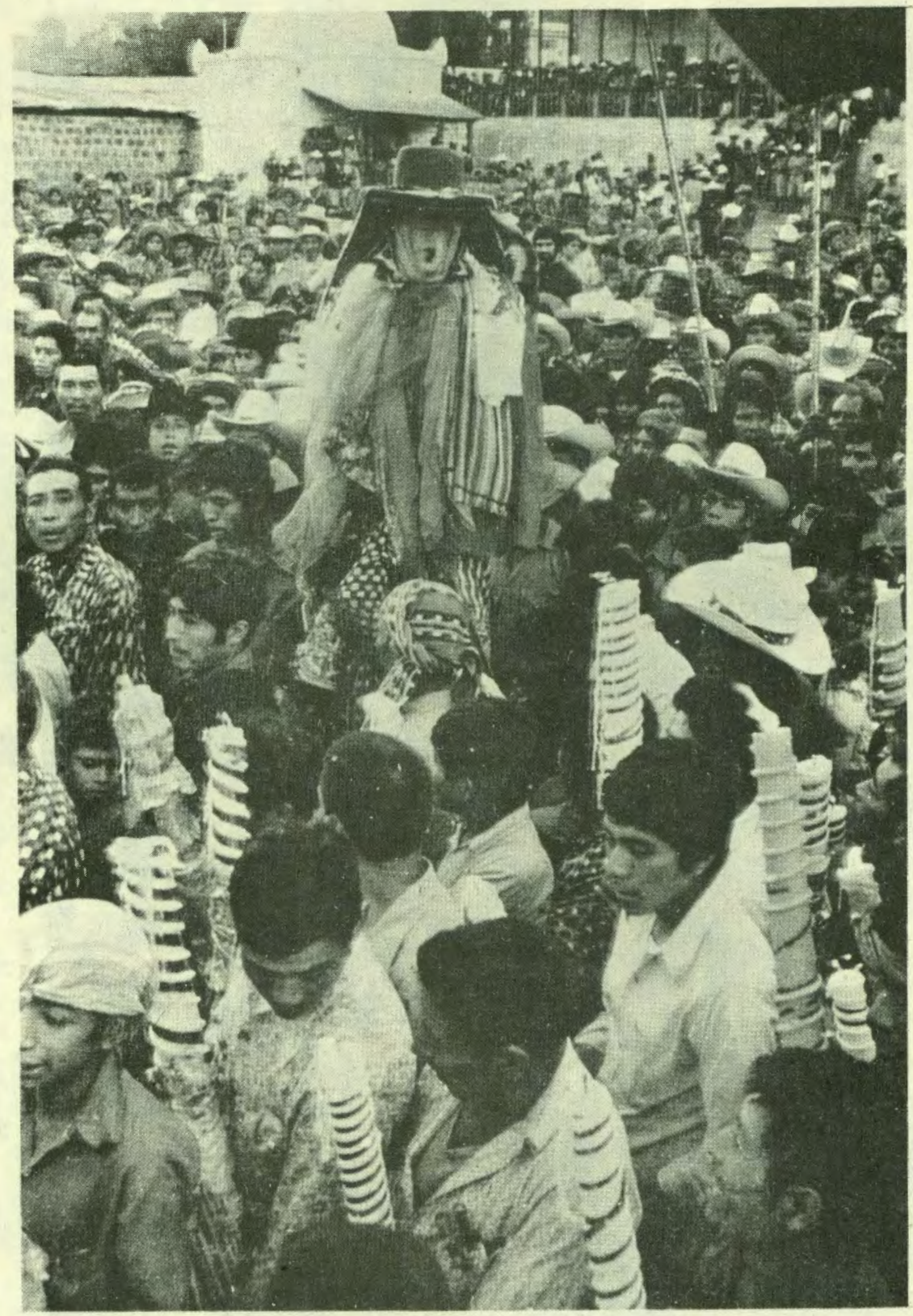

Figura 23: Procesión de Viernes Santo, con la imagen de Maximón en la plaza de Santiago Atitlán. 

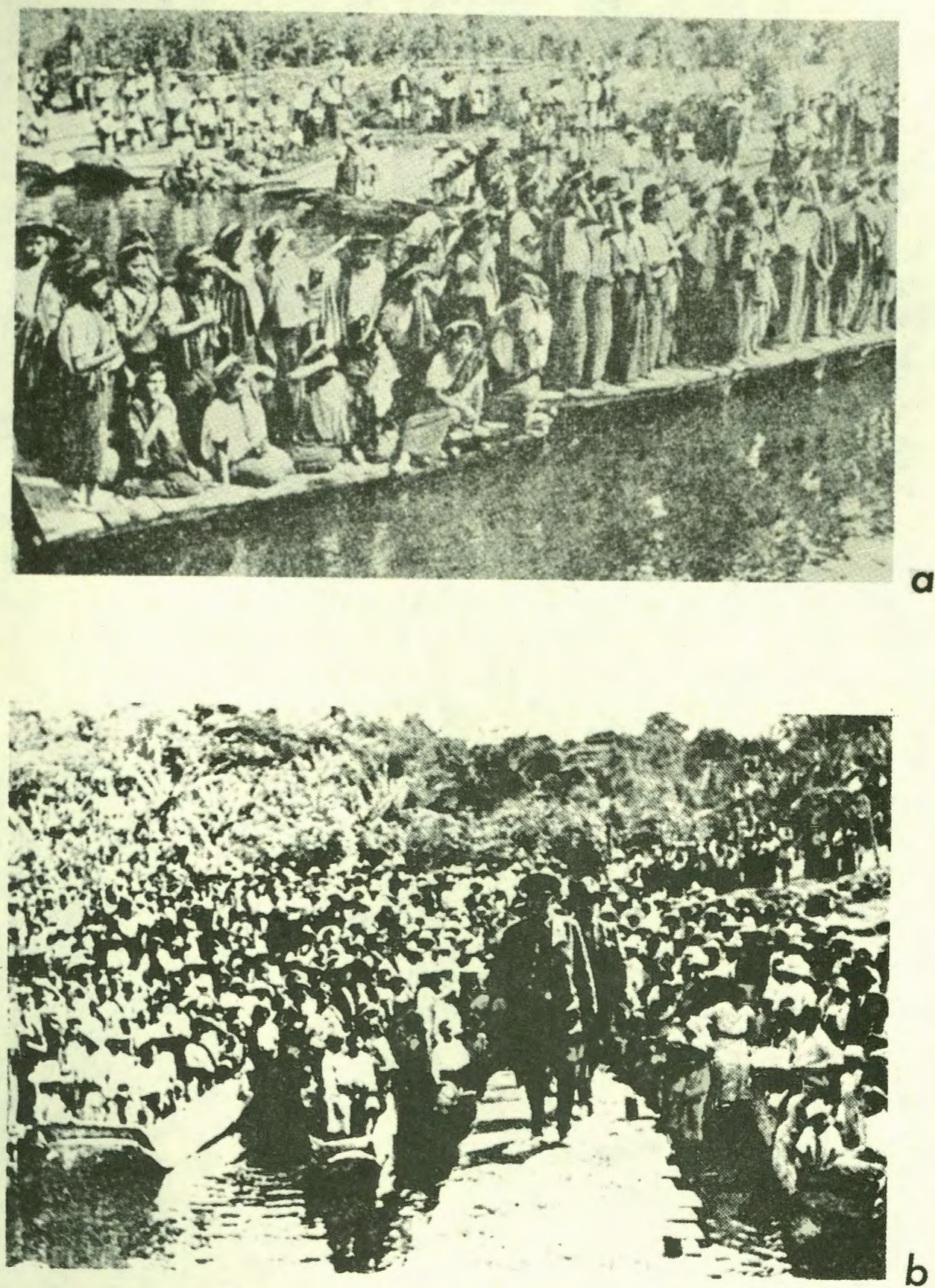

Figura 24: $a$, Mujeres de Santiago Atitlán, esperan en el muelle la llegada del Presidente Ubico; $b$, los atitecos, muy ordenados en sus canoas, sauldan al gobernante. 1943. 